\title{
Palaeozoic tectonic evolution of the Tianshan belt, NW China
}

\author{
Jacques CHARVET ${ }^{1 *}$, SHU LiangShu ${ }^{2}$, Sébastien LAURENT-CHARVET ${ }^{3}$, WANG Bo ${ }^{2}$, \\ Michel FAURE ${ }^{1}$, Dominique CLUZEL ${ }^{4}$, CHEN Yan $^{1} \&$ Koen De JONG ${ }^{5}$ \\ ${ }^{1}$ ISTO, Université d'Orléans, B.P. 6759, 45067 Orléans Cedex 2, France; \\ ${ }^{2}$ State Key Laboratory for Mineral Deposits Research, School of Earth Sciences and Engineering, \\ Nanjing University, Nanjing 210093, China; \\ ${ }^{3}$ Institut Polytechnique LaSalle Beauvais, Département Géosciences, BP 30313, 60026, Beauvais Cedex, France; \\ ${ }^{4}$ PPME, Université de la Nouvelle Calédonie, Noumea, New Caledonia; \\ ${ }^{5}$ School of Earth and Environmental Sciences, College of Natural Sciences, Seoul National University, Seoul 151-747, Korea
}

Received May 10, 2009; accepted November 27, 2009

\begin{abstract}
The Chinese Tianshan belt is a major part of the southern Central Asian Orogenic Belt, extending westward to Kyrgyzstan and Kazakhstan. Its Paleozoic tectonic evolution, crucial for understanding the amalgamation of Central Asia, comprises two stages of subduction-collision. The first collisional stage built the Eo-Tianshan Mountains, before a Visean unconformity, in which all structures are verging north. It implied a southward subduction of the Central Tianshan Ocean beneath the Tarim active margin, that induced the Ordovician-Early Devonian Central Tianshan arc, to the south of which the South Tianshan back-arc basin opened. During the Late Devonian, the closure of this ocean led to a collision between Central Tianshan arc and the Kazakhstan-Yili-North Tianshan Block, and subsequently closure of the South Tianhan back-arc basin, producing two suture zones, namely the Central Tianshan and South Tianshan suture zones where ophiolitic mélanges and HP metamorphic rocks were emplaced northward. The second stage included the Late Devonian-Carboniferous southward subduction of North Tianshan Ocean beneath the Eo-Tianshan active margin, underlined by the Yili-North Tianshan arc, leading to the collision between the Kazakhstan-Yili-NTS plate and an inferred Junggar Block at Late Carboniferous-Early Permian time. The North Tianshan Suture Zone underlines likely the last oceanic closure of Central Asia Orogenic Belt; all the oceanic domains were consumed before the Middle Permian. The amalgamated units were affected by a Permian major wrenching, dextral in the Tianshan. The correlation with the Kazakh and Kyrgyz Tianshan is clarified. The Kyrgyz South Tianshan is equivalent to the whole part of Chinese Tianshan (CTS and STS) located to the south of Narat Fault and Main Tianshan Shear Zone; the so-called Middle Tianshan thins out toward the east. The South Tianshan Suture of Kyrgyzstan correlates with the Central Tianshan Suture of Chinese Tianshan. The evolution of this southern domain remains similar from east (Gangou area) to west until the Talas-Ferghana Fault, which reflects the convergence history between the Kazakhstan and Tarim blocks.
\end{abstract}

Tianshan, NW China, tectonics, Paleozoic accretion

Citation: Charvet J, Shu L S, Laurent-Charvet S, et al. Palaeozoic tectonic evolution of the Tianshan belt, NW China. Sci China Earth Sci, 2011, 54: 166-184, doi: $10.1007 / \mathrm{s} 11430-010-4138-1$

\section{Introduction}

The Tianshan Mountains, extending over $3000 \mathrm{~km}$ from

*Corresponding author (email: Jacques.charvet@univ-orleans.fr)
NW China to Kazakhstan and Kyrgyzstan, constitute a major segment of the southern part of the Central Asia Orogenic Belt (CAOB), also referred to as Altaids [1-4]. Located between the Tarim Basin to the south and the Junggar Basin to the north (Figure 1), it is a key area for testing the 


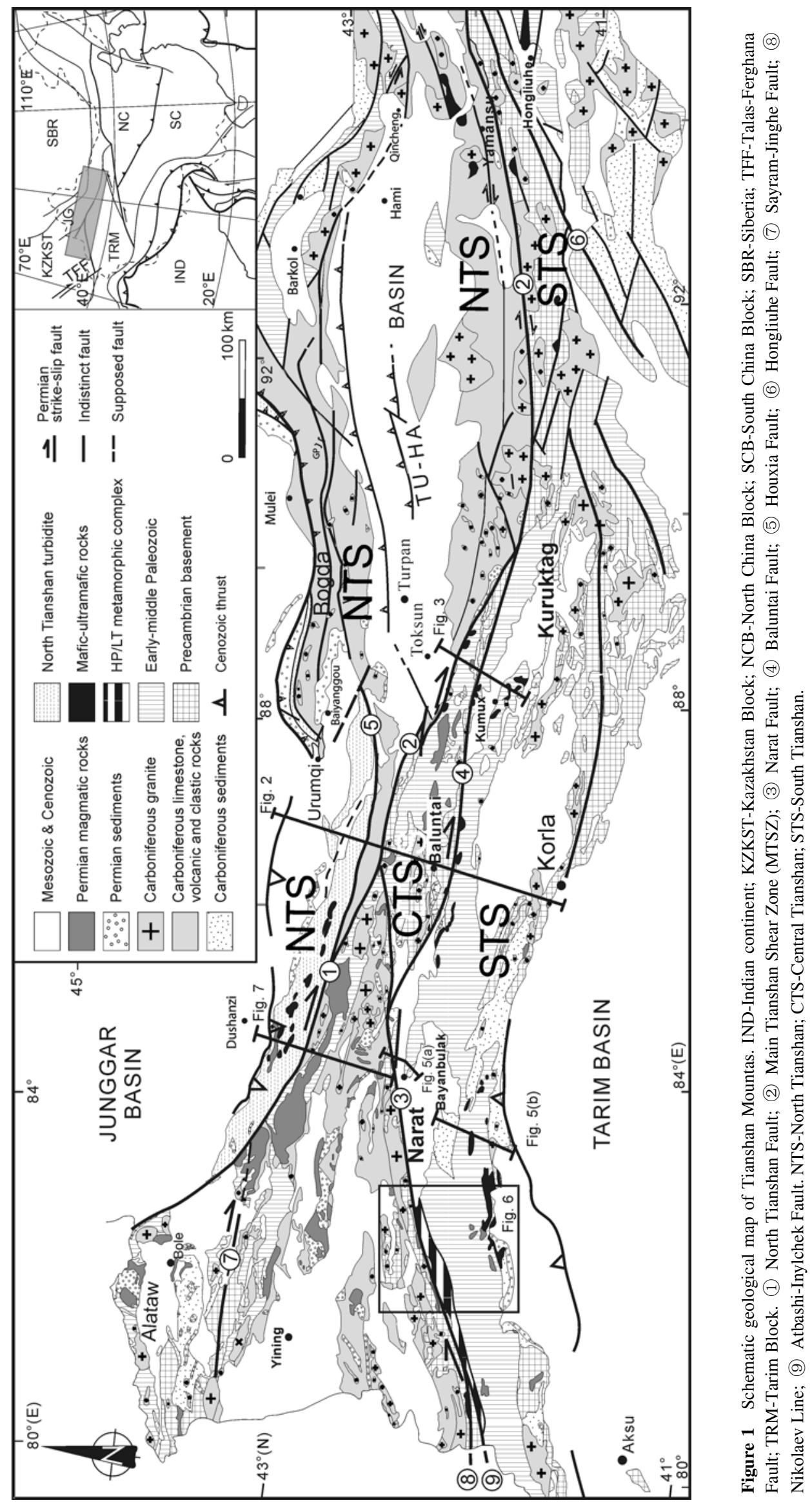


tectonic models of the CAOB. Two main stages of accretion/collision have been advocated [5-16].

The Chinese Tianshan is usually divided into North, Central, South Tianshan (NTS, CTS, STS), and Yili Unit also called Yili Block in the western part (Figure 1). At present, boundaries among NTS, CTS and STS are generally characterized by strike-slip shear zones that post-date the main accretionary events. In addition, the Cenozoic tectonism, due to Eurasia-India collision, is responsible for the recent southward thrusting of STS onto the Tarim Basin, and for the northward thrusting of NTS onto the Junggar Basin [6, 17-27]. The vergence and geodynamic significance of Paleozoic deformation events have long been debated, partly due to a lack of precise structural and kinematic analysis, as well as an absence of reliable data constraining the timing of various events. We present the $\mathrm{Pa}-$ leozoic tectonic evolution of the belt, taking into account recent data $[11,16,26-34]$ that lead to a reappraisal of the geodynamic model and the history of the southern CAOB. We suggest a new correlation with the westward extension of the belt, especially with the Kyrgyz Tianshan.

\section{General geological setting}

The main tectonic units of CAOB are shown in the simplified map (Figure 1) and the general cross-section (Figure 2).

NTS is a tectonic unit located to the north of the Main Tianshan Shear Zone [12, 35] (MTSZ, 2 in Figure 1) in the east and north of Narat Fault (3 in Figure 1) in the west. The northwestern extension of MTSZ is called North Tianshan Fault (NTF) [26-28, 31] (Figure 1 (1)). The Yili triangular unit, eastern extension of the Kazakhstan Block, is actually a part of NTS $[15,16,26,28,31]$ and should be considered to be a distinct unit with respect to CTS, unlike some of previous interpretations CTS [36-38]. The main characteristic is the presence of Upper Paleozoic (Late DevonianCarboniferous) sedimentary sequence and abundant calcalkaline volcanic and plutonic rocks [27] yielding zircon $\mathrm{U}-\mathrm{Pb}$ ages of 390-310 $\mathrm{Ma}$ [28, 39, 40]. Geochemical data suggest a continental active margin setting [11, 26-28, 39]. The existence of a continental basement, suggested by the geochemistry in the Bogda arc, is well documented in the Yili unit, where Proterozoic rocks are covered by a Lower Paleozoic continental shelf and slope sedimentary sequence [27, 36, 41, 42]. To the east of Urumqi, on the northern border, Upper Carboniferous turbidites overlie conformably arc-derived volcaniclastic sediments; to the west of Urumqi, they are in turn incorporated in an ophiolitic mélange, well represented at Bayingou, south of Dushanzi (Figure 1). The ophiolitic remnants include cherts that yield Upper Devonian-Lower Carboniferous radiolarians and conodonts [36, 42-44], while Early Carboniferous U-Pb SHRIMP zircon ages have been obtained, $344 \mathrm{Ma}$ for gabbro [45, 46] and 325 \pm 7 Ma for plagiogranite [47].

The entire NTS can be interpreted as a Late Paleozoic continental active margin bordering a southward-subducting oceanic domain located between NTS and Junggar unit. This subduction produced: 1) the Carboniferous volcanic arc represented by the Bogda arc to the east $[9,11,13,15$, 48], the volcanic-arc plutonic and volcanic rocks of Yili unit to the west [26-28, 30], and 2) trench-fill turbitites well preserved in the western area [42] and ophiolitic mélange, forming a suture zone between NTS and Junggar Block [28]. The main tectonic event took place before the sedimentation of unconformable Middle Permian red beds [9, 10, 14-16,

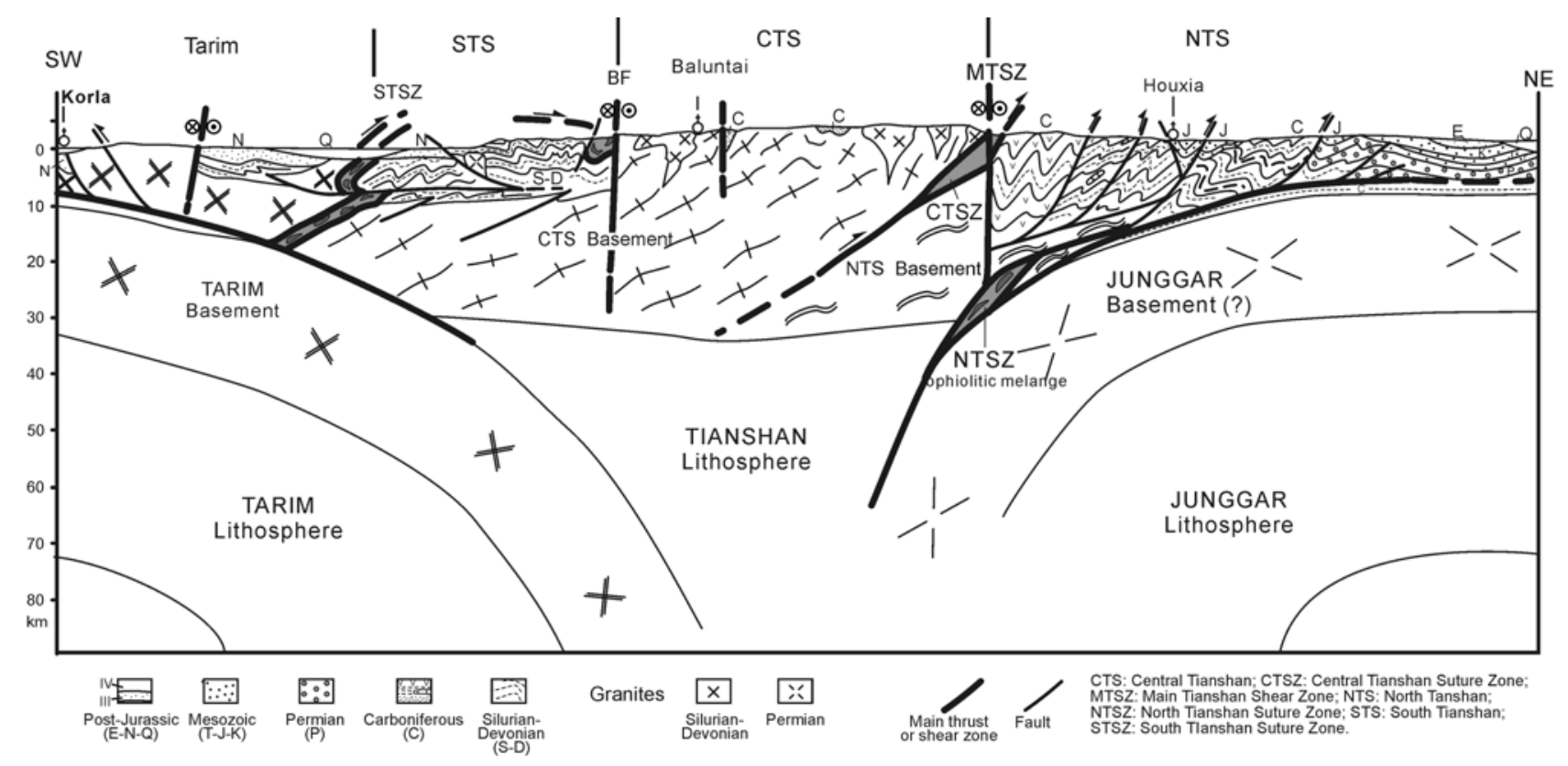

Figure 2 Simplified lithosphere-scale interpreted cross-section of Tianshan (location on Figure 1). Deep structure inspired from ref. [25]. 
$34,41,49]$ and the intrusion of Permian (280-265 Ma) granitic plutons [31].

CTS and STS extend to the south of Narat Fault and MTSZ (Figure 1) between the Central Tianshan Suture Zone (CTSZ) to the north, and the South Tianshan Suture Zone (STSZ) to the south (Figure 2). The boundary between them is defined differently by different authors, and commonly regarded to lie along major faults: the Baluntai Fault running from south of Baluntai to north of Kumux (Figure 1 (4)) and the Hongliuhe Fault (Figure 1 (6)). But this boundary is conventional and some rocks cropping out to the south of Baluntai Fault are still a part of the CTS Lower Paleozoic paleogeographic unit, which is in fact the relative autochthon of STS nappes [16, 29, 31].

CTS is characterized by a Proterozoic basement composed of gneiss, amphibolites and marbles [34, 41, 50-55], some Lower Paleozoic granitic gneisses and metasandstone including Ordovician-Silurian volcanic-arc rocks [55, 56], Silurian flysch $[9,10,12,15]$, subduction-related Silurian-Early Devonian plutonic rocks $[57,58]$, and post-orogenic Late Devonian granites [59]. A major feature is the angular unconformity of Lower Carboniferous conglomeratic molasse, which clearly overlies various older rocks: Ordovician-Silurian schist, gneiss, or Devonian granite [10, $11,13,14,29,41,53,60]$. Rare volcanic rocks interbedded within the Carboniferous molasse (i.e. seen at Luotuogou near Baluntai, Figure 1), are alkaline, indicating a post-tectonic rifting episode [47], whereas calc-alkaline volcanic rocks are missing. Along the northern boundary of CTS, relics of ophiolitic mélange are preserved discontinuously in eastern Tianshan. They comprise blocks of serpentinite, peridotite, gabbro, marble, and chert involved in a highly schistose flysch /tuff matrix [7, 10, 11, 61-63], and rare HP/LT metamorphic rocks [36, 64]. The ophiolitic remnants have a N-MORB type geochemical signature [11, 62, 64]. To the west of Bayanbulak, south of Narat Fault, this suture is represented by a metamorphic complex [26, 29, 31, 33], divided into two subunits: a northern one containing blocks of blueschist and eclogite, and a southern one composed of greenschist $[29,31,65,66]$. The protoliths are interpreted as ocean-derived, with MORB and OIB signatures [31, 65]. ${ }^{40} \mathrm{Ar} /{ }^{39} \mathrm{Ar}$ dating of white mica from variably retrogressed blueschists and greenschists gives ages of 350-345 Ma (peak metamorphism) to $310 \mathrm{Ma}$ (retrograde metamorphism) [44, 66-68]. Some of these Ar/Ar ages suggest a Late Carboniferous fluid mediated recrystallization $[31,32,68]$. The mélange, which contains Silurian limestone blocks [41, 65], was intruded at Gangou by a granodiorite around inherited cores, the rims of zircons extracted from this intrusive rock give a U-Pb age of $366.1 \pm 8 \mathrm{Ma}$ [69]. The formation age of this mélange is therefore likely to be Middle-Late Devonian, pre-dating the Visean molasse that overlies the structures with an angular unconformity [60]. In the southern part of CTS, to the south of the arc-related rocks, the autochthonous Paleozoic cover only contains sedimentary rocks: Up- per Ordovician to Silurian limestones or calcareous turbidites, grading into Upper Silurian calcareous flysch in the northern part [11, 70], and Lower Devonian limestones grading into cherty limestones and then cherts in the southern part $[11,16,70]$. These strata were locally metamorphosed and had experienced ductile deformation, especially in the south, and are affected by contact metamorphism due to granite intrusions.

STS differs from CTS in several aspects [16, 29, 31]. The main characteristic is the existence of allochthonous units of ophiolites and ophiolitic mélanges, well represented in $\mathrm{Ku}-$ mux and Hongliuhe areas of East Tianshan [10, 11, 62], and in the Heiyingshan and Aheqi mélanges of West Tianshan $[26,29,31]$. They locally contain relics of blueschists and HP-type granulite [63, 65, 71]. The mélanges have been initially assigned to the Silurian [41]. However, LowerMiddle Devonian radiolarians in a chert olistolith [36] and radiolarians found in the matrix and cherts ranging from Upper Devonian to Lower Carboniferous [72-74] argue for an Early Carboniferous age, as it is unconformably overlain by Lower Carboniferous (Visean) conglomerate. Recent radiometric age data confirm the assumption: in Kumux area, the granulite of Yushugou ophiolitic body yields zircon U-Pb SHRIMP ages of 390 \pm 11 and $392 \pm 7$ Ma [75] and a block of blueschist gives an ${ }^{40} \mathrm{Ar} /{ }^{39} \mathrm{Ar}$ age of $360.7 \pm 1.6$ Ma [71]. In West Tianshan, in the Heiyingshan mélange, a gabbro gives, by zircon U-Pb LA ICP MS method, an age of $392 \pm 5 \mathrm{Ma}[29,31]$. Therefore, the oceanic lithosphere was, at least partly, created during the Early Devonian and emplaced, together with HP metamorphic rocks, around the Devonian-Carboniferous boundary.

The geochemical features of mafic rocks that form the mélange suggest a back-arc basin setting [11, 62, 64, 76]. These ophiolite and ophiolitic mélanges were initially assumed to be rooted to the north and emplaced from north to south, onto the Tarim passive margin, after a northward stage of subduction $[6,7,36,37,42]$. But our kinematic studies indicate that these nappes were actually emplaced from south to north, in East Tianshan [10, 11, 13-16], and in West Tianshan as well $[26,29,31,33]$. Therefore, the root is located to the south, a hidden zone between the ophiolite outcrops and the Tarim. Unfortunately, in West Tianshan, the root zone cannot be found and is now hidden, due to Cenozoic reactivation by southward thrusting. In East Tianshan, the original geometry, inherited from the Paleozoic, is less disturbed in the Hongliuhe area where a proximal mélange linked to the Tarim upper plate is seen overthrusting northwards the ophiolitic mélange $[11,16]$, despite a post-Permian reactivation.

In summary, CTS and STS are bounded by a northern suture corresponding to the Devonian closure of an oceanic domain, and a southern suture corresponding to the Earliest Carboniferous closure of a back-arc basin. During the Silurian-Devonian, they constituted a single paleogeographic unit, containing a volcanic arc in the northern part. 
The last and southernmost subunit corresponds to the deformed northern edge of the Tarim Basin. It contains Sinian to Ordovician platform sedimentary rocks: limestone and shale [60]. The Sinian and Cambrian may contain intercalations of rift-related volcanic rocks [47]. The Silurian, overlying the older rocks with a slight unconformity [60], begins with a conglomerate and includes several polygenetic conglomeratic layers in a flysch-like series. It grades into an olistostrome, with huge olistoliths, to the south of Hongliuhe, marking a period of instability [16]. Upper Devonian-Lower Carboniferous arc-related plutonic rocks occur at the northern edge of Tarim Basin [77, 78]. Close to the STS boundary, Lower Carboniferous to Lower Permian fluvial and marine deposits overlie Sinian to Devonian rocks with angular unconformity [29, 31, 60]. The Lower Permian strata contain rift-related volcanic and volcaniclastic rocks dated at $275-280 \mathrm{Ma}\left({ }^{40} \mathrm{Ar} /{ }^{39} \mathrm{Ar}\right.$ on feldspar) and were in turn unconformably overlain by Upper Permian detrital series [60].

The Paleozoic build-up of the Tianshan Mountains can be divided into two stages. The first one, ending in the Early Carboniferous, built the Eo-Tianshan Orogen [16]. The second one, after the subduction responsible for the NTS arc, led to the Late Carboniferous-Early Permian amalgamation. In the next section, we will examine the tectonic features of the first event, which are mainly recorded in CTS and STS.

\section{Pre-Carboniferous tectonics of Central and South Tianshan: birth of Eo-Tianshan}

Starting from the section in Kumux-Toksun area (Figures 1 and 3) as a reference example in East Tianshan, we will take complementary information from sections in Bayanbulak and Koksu areas in West Tianshan.

\subsection{Kumux-Toksun}

The likely best example of the South Tianshan ophiolitic zone, with the Yushugou ophiolitic body (Figure 3), is exposed in the Kumux area. The Yushugou ophiolitic body tectonically overlies a block-bearing metamorphosed flysch, cropping out to the south, which is intruded and contactmetamorphosed by an undeformed granite (Figure 3), presumably the Early Permian age $[10,56]$.

The schistose meta-flysch is Late Devonian-Early Carboniferous as discussed earlier. The overlying units are: a mélange with a schistose serpentinitic matrix, including blocks of marble, basalt, peridotite, altered gabbro and dolerite; a unit of foliated granulite, which was derived from gabbro, basalt, and greywacke; a last unit of layered gabbro and pyroxenite, which disappears beneath the recent deposits of the Kumux basin. Thermo-barometric data indicate for the granulite a peak temperature between 658 and $964^{\circ} \mathrm{C}$ and a peak pressure ranging from 0.88 to $1.5 \mathrm{GPa}$, depend- ing on the barometers used [63, 71, 72]. SHRIMP U-Pb datings of zircons give ages of $390 \pm 11,392 \pm 7$ and $398 \pm 4$ Ma [75].

The Tonghuashan and Liuhuangshan ophiolitic mélanges, located nearby, comprise three types, depending upon their matrix: 1) a matrix of greenschist including blocks of marble and limy conglomerate; 2) a tuffaceous matrix with blocks of quartzite, crinoidal limestone, red chert, gabbro, basalt, peridotite, serpentinite; and 3) a serpentinitic matrix with ultramafic blocks. The greenschist matrix is a meta-flysch, with a few blueschists relics in Tonghuashan [65]. Lower-Middle Devonian radiolarians from chert of the Liuhuangshan mélange [36] indicate a Middle Devonian maximum age.

The Kumux-Gangou segment of the section crosses the northern part of STS and the CTS, up to the CTSZ Gangou mélange (Figure 3). It begins with a series of gneiss and micaschist including lenses of mylonitized granite dated at $396 \mathrm{Ma}$ [55], metamorphosed under lower-amphibolite to greenschist facies conditions, likely an analogue of the Silurian-Devonian schist-marble series that crop out along the northern edge of STS further to the west [31, 70]. An E-W trending shear zone, several tens of meters wide, marks the Baluntai-Sangshuyuanzi Fault, a conventional boundary of CTS [9-11, 64]. It shows clear dextral strike-slip kinematic criteria, associated to a conspicuous subhorizontal stretching lineation, whereas some minor conjugate shear zones, trending ca. $50^{\circ} \mathrm{N}$, are left-lateral $[11,56]$. Orthogneiss and paragneiss that crop out to the north, with intercalations of quartzite, micaschist, amphibolite, and marble, are assumed to represent the Proterozoic basement of the CTS $[5,7,10$, $11,16,36,56]$. Granites, granodiorites and undeformed pegmatite dykes crosscut the metamorphic rocks. A zircon $\mathrm{U}-\mathrm{Pb}$ age of $1013 \pm 66 \mathrm{Ma}$ and a zircon $\mathrm{Pb} / \mathrm{Pb}$ age of $960 \mathrm{Ma}$ were obtained for these granites [79]. The pegmatites are associated with small granitic plutons, dated at Permian [26]. A fault contact bounds the gneiss and schistosed Ordovician greenish metagreywacke [64], which includes andesite, dated at $477 \mathrm{Ma}$ by $\mathrm{Rb}-\mathrm{Sr}$ method [64] and yields Lower Ordovician fossils [11]. It is intruded by foliated gabbros, assigned to a continent-based volcanic arc setting [11]. At Ma'anqiao, overturned non-schistose Lower Carboniferous red conglomeratic molasse overlies unconformably Silurian flysch, affected by a south-dipping schistosity. Tuffaceous layers suggest a volcanic activity during the Silurian.

A reverse fault marks the contact with the Lower Carboniferous conglomerate grading upwards into coralbrachiopoda-bearing limestone. The conglomerate is composed of basalt, gabbro, schist, granite, and Devonian grey limestone pebbles [64]. To the north, the Lower Carboniferous conglomerate overlies with a clear angular unconformity the schistose Ordovician greywackes. The Ordovician sequence includes basalt, andesite, and minor dacite and rhyolite, having a continent-based island arc signature 


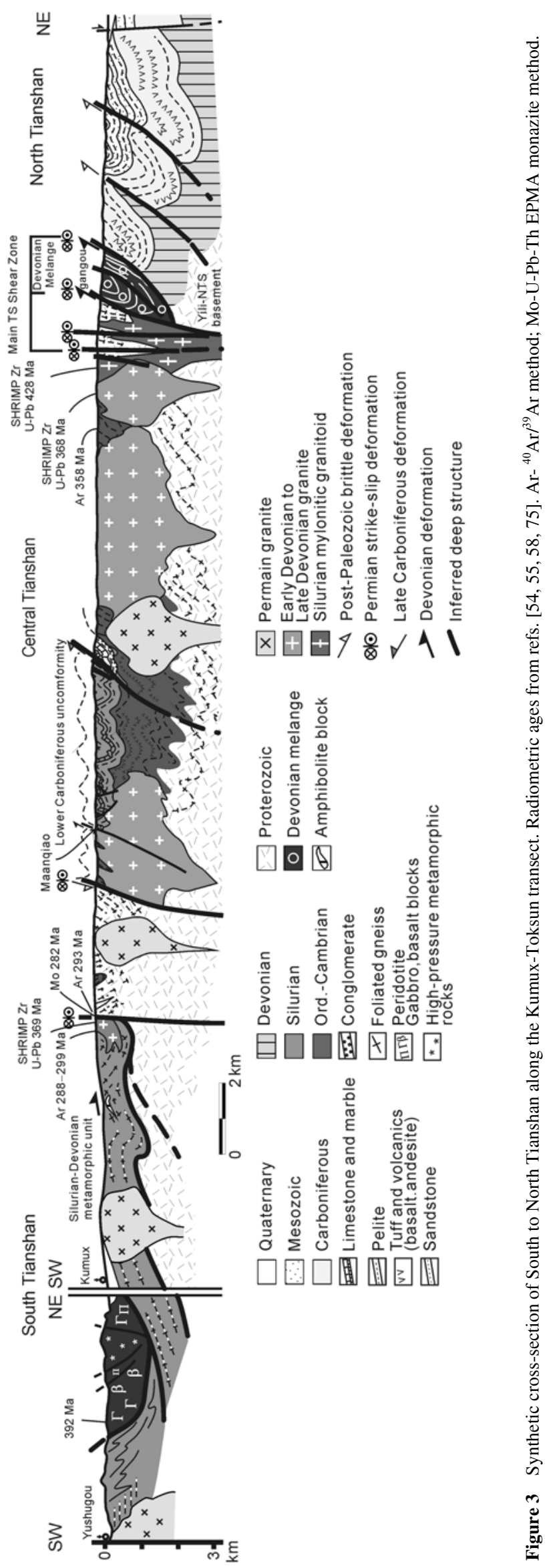


$[10,11]$. Several intrusive granodiorite bodies develop locally contact metamorphism (andalusite spots), and one of them has been dated at $457.4 \pm 1.8$ Ma by zircon $\mathrm{U}-\mathrm{Pb}$ method [80]. Calc-alkaline bodies, giving TIMS U-Pb ages from $424.1 \pm 1.1$ to $393.2+1.4 \mathrm{Ma}$ [57], represent likely the deep part of an Ordovician-Early Devonian arc, as the aforementioned gabbros. A post-tectonic intrusive is similarly dated at $327.3 \pm 0.9 \mathrm{Ma}$ [57], and the undeformed fine-grained granite located about $2 \mathrm{~km}$ south of CTSZ gives a SHRIMP zircon $\mathrm{U} / \mathrm{Pb}$ age of $368-361 \mathrm{Ma}$; its geochemistry is similar to that of adakitic rocks formed by partial melting of thickened mafic lower continental crust [59]. The augen orthogneiss (Figure 4(a)) marking the end of CTS displays several dextral and minor sinistral shear zones, and some relics of thrust indicators, and it yields a SHRIMP zircon $\mathrm{U}-\mathrm{Pb}$ age of $428 \pm 10 \mathrm{Ma}[59,81]$. It is bounded to the north by a steeply dipping $100^{\circ} \mathrm{N}$ trending fault, atop the Gangou mélange zone. The fault, a branch of MTSZ, shows evidence of recent brittle motion reworking the older ductile strike-slip mylonite $[12,35]$.

Between the gneiss and the NTS Carboniferous andesites, the Gangou mélange zone is composed of several faultbounded units. A coloured mélange yields olistoliths of serpentinite, gabbro, pyroxenite, basalt, meta-tuff, chert, and marble. This ophiolitic mélange $[7,10,11,62,63]$ is a part of the CTSZ accretionary wedge $[10,11,14,15,26,31,62$, 75]. As previously discussed, the formation age is likely Devonian. The contact between the mélange zone and North Tianshan Carboniferous volcanic rocks indicates a top-tonorth motion.

The interpretation of structures and microstructures shows a polyphase deformation.

Some microstructures within the Proterozoic basement are possibly inherited from pre-Paleozoic tectonic events, including south-verging shearing $[11,56]$. Regarding the deformations that affect the Paleozoic rocks, three main stages of ductile deformation can be recognized: 1) preCarboniferous north-vergent folding and thrusting; 2) postCarboniferous south-verging folding; and 3) Permian right-lateral strike-slip.

Paleozoic structures created prior to the Carboniferous unconformity are ubiquitously north verging $[10,11,14-16$, 26, 31, 63] (Figure 4(b)). In thin section, all kinematic criteria indicate a top-to-the north (from NW to NE) sense of shear [16]. The CTS Paleozoic formations, affected by an early deformation marked mainly by north-vergent folds, show a cleavage $S 1$ well developed and sub-parallel to $S 0$ in the Ordovician, but less penetrative and parallel to axial planes in the Silurian. The Gangou mélange shows some relics of an early northward ductile shearing.

Post-Carboniferous south-verging folding and thrusting are obvious. The Lower Carboniferous unconformity is folded with a southern vergence and Carboniferous strata are locally schistose. Although it is difficult to determine the age of this deformation, there are some lines of evidence for a pre-Permian folding [16], which could be synchronous with the second accretionary event involving NTS arc, like in West Tianshan [33].

The third tectonic event is a Permian right-lateral strike-slip. In several places, especially along the main faults (Baluntai Fault, MTSZ), a steep $100^{\circ}-120^{\circ} \mathrm{N}$ trending foliation bears a sub-horizontal lineation. It affects Gangou mélange, Ordovician volcaniclastic rocks, granites, and the Proterozoic basement. A cleavage with the same attitude is also observed in the southern edge of NTS Carboniferous andesites $[11,12,35]$. The kinematic criteria are clearly dextral; in granitic mylonites, sinistral metre-scale steep shear zones, trending around $40^{\circ}-60^{\circ} \mathrm{N}$, are interpreted as minor conjugate faults of the main shear zone. In the gneissic rocks, the strike-slip deformation is locally accompanied by retrograde metamorphism, from biotite being transformed into chlorite. Quartz LPO analysis confirms dextral motion and indicates, by the activation of basal plane gliding system, a temperature below $300^{\circ} \mathrm{C}[10,11$, $12,35]$. Ar-Ar dating on micas gives ages of $290 \mathrm{Ma}$ for a first stage in HT to MT conditions, and 250-245 Ma for a second stage in MT to LT conditions [35]. A 282 \pm 9 Ma age is obtained near the Baluntai Fault [56]. Evidence of such Permian dextral strike-slip shearing extends to West Tianshan along the Narat and others faults [26, 28, 31, 55].

The Mishigou section, located about $30 \mathrm{~km} \mathrm{SW}$ of Toksun, confirms the data observed in Kumux-Toksun section, regarding: the northward vergence of the first deformation in the Silurian flysch, the Ordovician volcanic rocks, and the CTSZ mélange; and a second schistosity, dipping to the north, that crosscuts the clear Carboniferous unconformity [16] (Figure 4(c)).

In summary, the transect of Kumux-Toksun area, including Mishigou, shows: 1) a pre-Carboniferous northverging tectonic event responsible for the emplacement of the South Tianshan ophiolites, thrusting of an Ordovician-Early Devonian island arc, emplacement of the Gangou-Mishigou ophiolitic mélange, forming the northern suture; 2) south-verging post-Carboniferous folding, likely post-dated by the Permian unconformity; and 3) a Permian dextral strike-slip shearing.

\subsection{Bayanbulak transect}

In West Tianshan, north of Bayanbulak Basin (Figures 1 and 5), the Silurian CTS arc [41] is in fault contact to the north with the Proterozoic Narat complex, composed of migmatite, para and orthogneiss, amphibolite, frequently mylonitized granite. Previous radiometric data from orthogneiss [70] give ages of $1.3 \pm 0.2$ (zircon $\mathrm{U} / \mathrm{Pb}$ ) and $1.1 \pm 0.125 \mathrm{Ga}(\mathrm{Sm}-\mathrm{Nd}$ whole rock), and more recent ones yield ages of $707 \pm 13$ and $882 \pm 33 \mathrm{Ma}$ (zircon U-Pb) [82, 83]. The boundary between CTS and the Yili-NTS is marked by the Narat Fault, separating greenish tuffs and grey sandy limestone intercalated with reddish pelite and cong- 

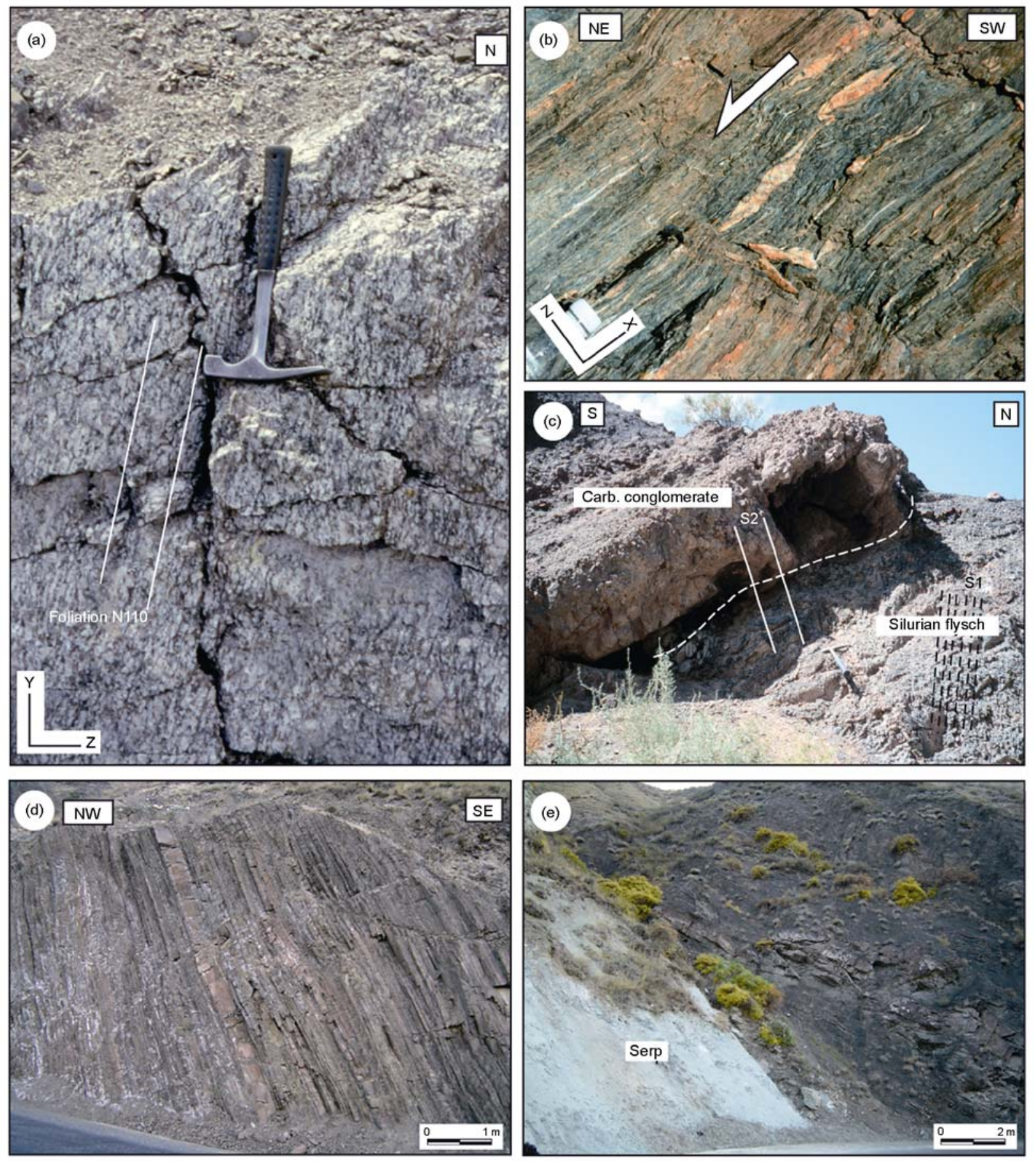

Figure 4 Outcrop views. (a) Polydeformed augen orthogneiss in the MTSZ, Kumux-Toksun cross-section, protolith dated at 428 \pm 10 Ma [58]; (b) top-to-the-north kinematic criteria, Yushugou schists, STS; (c) unconformity of the Lower Carboniferous molasse conglomerate above the Silurian flysch, Mishigou, CTS; (d) Upper Carboniferous turbidites, Bayingou section, NTS; (e) serpentinite olistolith in the Carboniferous Bayingou ophiolitic mélange, NTS.

lomerate, dated as Silurian [70], and the Carboniferous andesites. Along strike toward the east, Carboniferous sedimentary rocks of CTS are exposed near the Qiaohuote copper mine, and the Lower Carboniferous basal cong- lomerate overlies the schistose and slightly metamorphosed Silurian tuff and andesite with angular unconformity. A few kilometres to the south of Bayanbulak (Figure 5(a)), the Carboniferous series begins with a conglomerate, including boulders of Devonian granite [26,54] that it unconformably overlies Silurian rocks, and grades into sandstone, then limestone, and ends with an Upper Carboniferous flyschlike sequence, locally overturned to the south. 

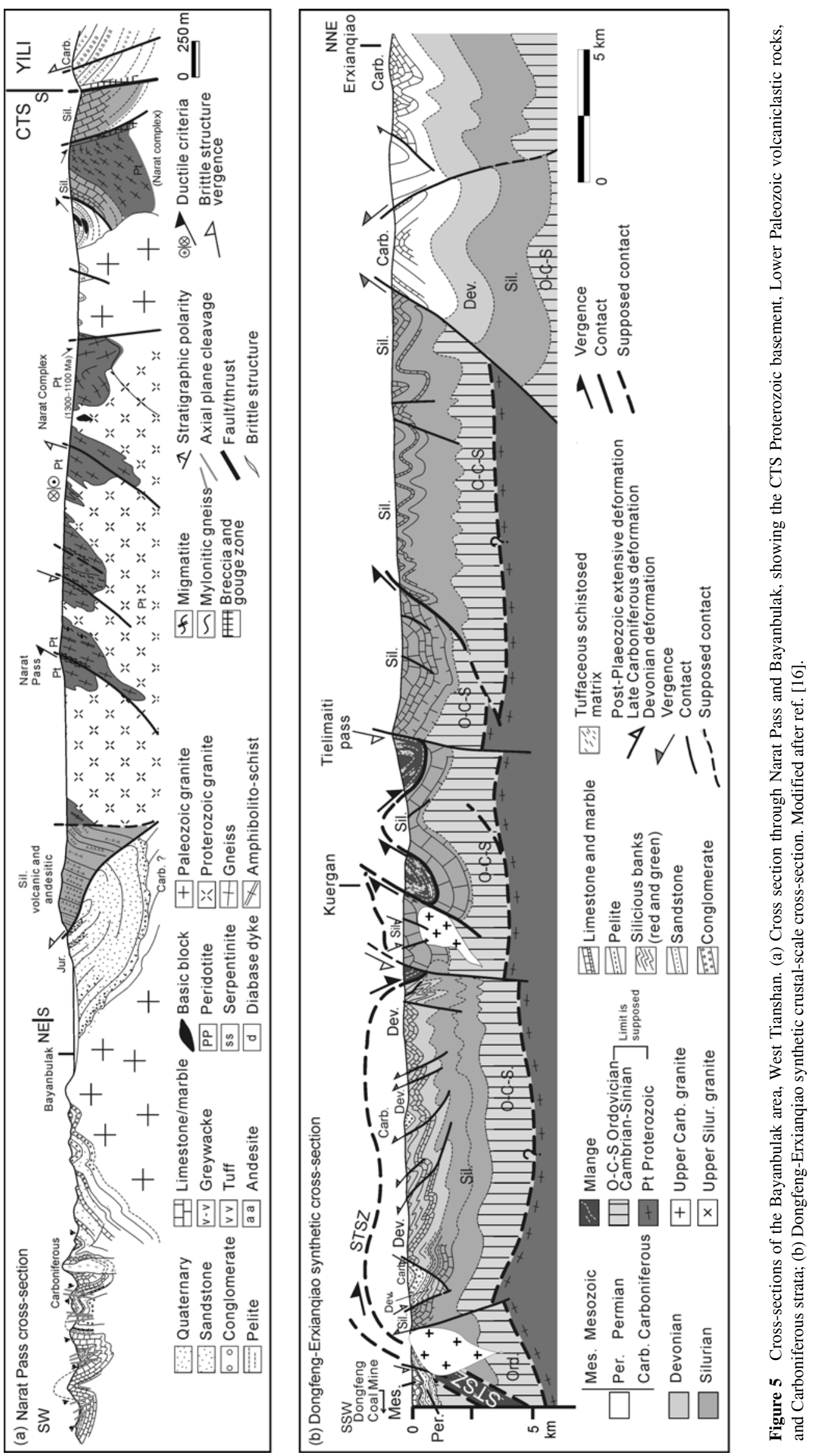
The Erxianqiao-Dongfeng section (Figure 5(b)) crosses CTS and STS. The northern part is made of fossiliferous Lower Carboniferous limestone and pelite [70], and Upper Carboniferous limestone and siliciclastic rocks [64]. In the south, near the Tielimaiti Pass, Upper Silurian calcareous flysch and Upper Silurian limestones crop out. At the southern foot of Tielimaiti Pass, the klippe of Dalaoba (Kule Lake)-Kuergan ophiolitic mélange is in fault contact with the Silurian limestones. Radiolarian fossils found in cherts give a Late Devonian-earliest Carboniferous age for the mélange [73]. It contains blocks of chert, marble, limestone, and oceanic rocks yielding U-Pb SHRIMP/LA ICPMS ages of 425-395 Ma [84]. The autochthonous unit contains, in the northern segment, Middle Silurian marbles [70] and some conglomeratic layers. Intercalated marbles and pelites are affected by contact metamorphism, associated with 426-425 Ma arc-related granitic intrusions [56]. To the south, the outcrops are mainly Devonian, composed, from bottom to top, of massive and bedded limestone, mudstone, well bedded red or green chert, overlain by a likely unconformable sequence of sandstone (Carboniferous ?) beginning by a conglomerate. The end of the section bears fault-bounded granite, unconformably overlain by Permian conglomerate that is in fault contact with Triassic strata.

Near Narat, the early (pre-Carboniferous) ductile structures and microstructures seen in the Silurian indicate a top-to-north shearing along a lineation trending between $330^{\circ} \mathrm{N}$ and $30^{\circ} \mathrm{N}$. Similar features are present in the gneissic basement. Several south-verging brittle structures, such as Proterozoic-Silurian and Silurian-Carboniferous boundaries, thrust of Silurian above Jurassic, even a low angle thrust of NTS (Yili) Carboniferous andesites over the Jurassic conglomerate, are clearly younger than Jurassic in this area [16]. The Carboniferous section near Bayanbulak also shows south-verging folds, and the age of folding, poorly constrained, could be partly post-Jurassic. If the ductile deformation of the Kule Lake mélange is oriented northward, as suggested by several kinematic criteria, and if north-vergent sub-isoclinal folds are also present in the Middle Silurian, Lower Devonian, and Upper Silurian strata [16] such structures are refolded by well developed south-verging folds, that also affect the Carboniferous. The age of this deformation is difficult to assess but this southward folding initiated likely prior to the Permian unconformity [16]. Thus, it was likely due to the second collision [16] as it is inferred also to the west [33].

Thus, we find the same tectonic scenario as in $\mathrm{Ku}$ mux-Toksun sections in East Tianshan. Here the equivalent of Gangou-Mishigou mélange is missing, truncated by the Narat Fault. But the advantage of this section is to show the sedimentary cover of CTS lying to the south of the volcanic arc. The sedimentary sequence exposed in the south, beginning with platform strata, suggests a deepening of the depositional environment during the Devonian. This section also indicates that the classical distinction between CTS and STS is purely conventional. Actually, from Narat Pass area to the ophiolitic suture to the south, one remains in the same Paleozoic paleogeographic zone, relative autochthon of ophiolitic nappes, bearing an Ordovician-Lower Devonian arc in its northern part.

\subsection{Koksu area}

Further west, in the area of Koksu River, on northern Halik Mountain (Figure 6) the CTSZ is not affected by the Narat Fault that runs further north within the Yili unit $[26,29]$. There, one can see the HP/UHP paleo-oceanic metamorphic units of the suture overthrusting the micaschists and quartzites of Yili basement. These HP and UHP rocks include relics of well-studied blueschists and eclogites [31, 66, 85]. The protoliths represent an oceanic crust submitted to a subduction-collision event $[65,66]$. In the HP metamorphic rocks and in the gneiss and quartzite of the autochthonous Yili unit, the kinematic criteria indicate a top-to-the-north shearing [26, 31, 65]. Isotopic ages of blueschists and eclogites are around $350 \mathrm{Ma}[44,65,66]$, and show retrogression that occurred at 330-310 Ma [66, 68]. The Carboniferous $(341 \pm 6$ and $338 \pm 8 \mathrm{Ma})$ granitic intrusions that crosscut the Yili basement are undeformed [29, 31]. We conclude that this section records the initial northward thrusting (Late Devonian-Early Carboniferous) of the oceanic rocks upon the Yili-NTS continental basement.

Further west in China, this suture zone exhibits the same kinematic characteristics and the same pre-Carboniferous northward emplacement [33, 34]. Even though ages of about 420 Ma obtained from zircon cores [38] give a meaningful Devonian age for the oceanic protoliths, a Triassic metamorphic age [38] contradicts the regional geology, and is better explained by a fluid mediated recrystallization [32, 34]. This suture zone extends southwestwardly to Kyrgyzstan, in the Atbashi Ridge, where ${ }^{40} \mathrm{Ar} /{ }^{39} \mathrm{Ar}$ ages of $327.1 \pm 4.2$ and 324.2 \pm 9.7 Ma were obtained from eclogites [86].

\subsection{Summary of the first accretion-collision stage: birth of Eo-Tianshan Mountains}

STS and CTS were amalgamated to the Tarim Plate, prior to the Visean unconformity, due to a tectonic event involving the formation of two suture zones: the Central Tianshan Suture Zone to the north, the South Tianshan Suture Zone to the south. The CTS was thrust northward onto the NTS-Yili pre-Carboniferous basement, as seen in Koksu section. The Central Tianshan Suture Zone corresponds to the closure of an oceanic domain, which was subducted southward beneath Central Tianshan during the Ordovician to Early Devonian. During Late Devonian, the closure led to the collision between the CTS arc and the Yili-NTS basement. The STS nappes were a bit later thrust northward onto the southern part of CTS arc. The Tarim Plate was the hinter 


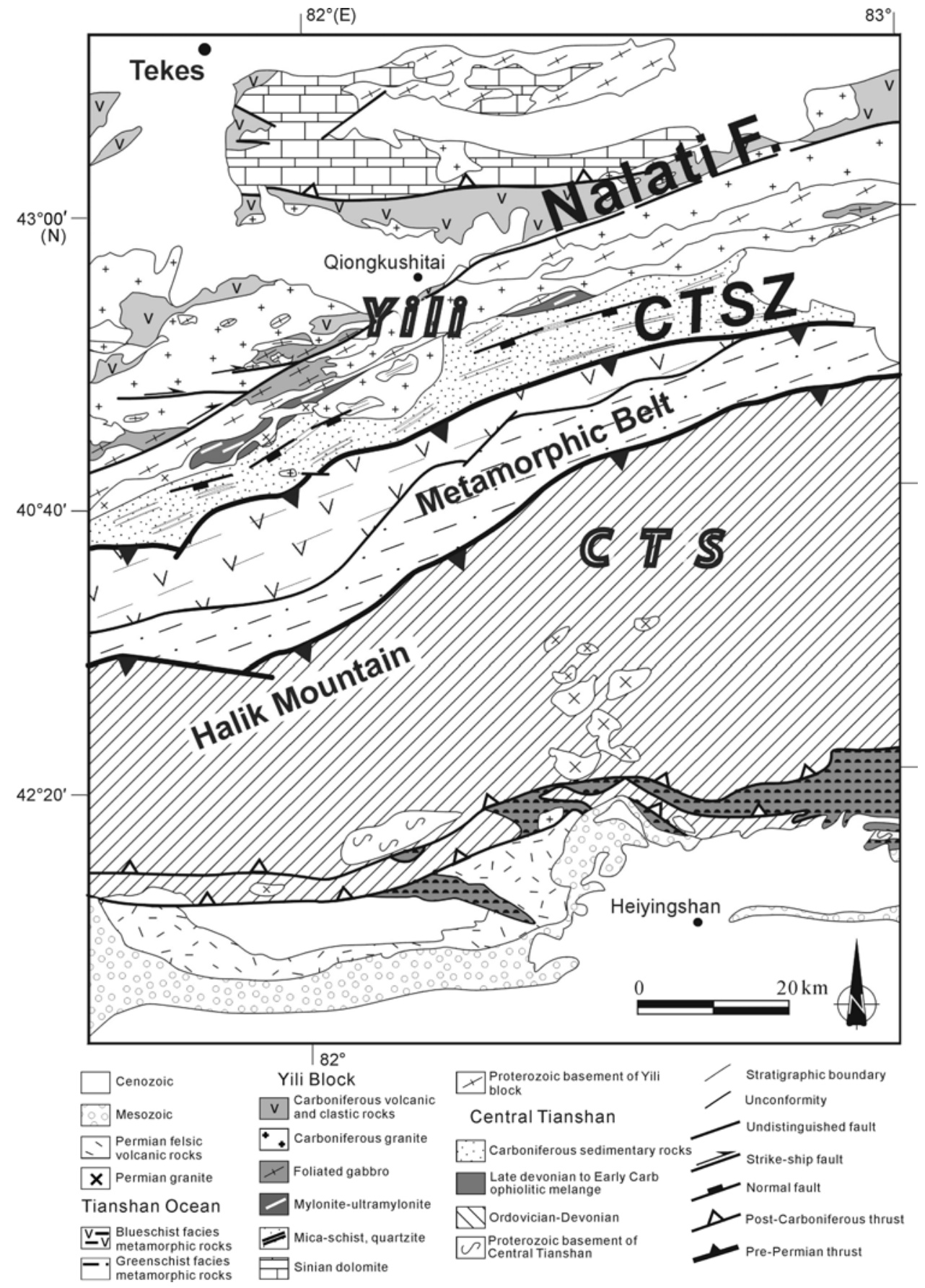

Figure 6 Geological map of Heiyinshan-Koksu area. Modified after ref. [29].

land, the upper plate thrust over the STSZ. It records magmatic arc activity during the Late Devonian-Early Carboniferous [77], interpreted as the closure time of the back-arc basin by southward subduction. In summary, this first stage corresponds to the amalgamation of Yili-NTS and Tarim blocks, giving birth to the Eo-Tianshan Mountains, which has the characteristics of a collisional belt: ophiolites, HP and UHP metamorphic nappes, molasse, post-tectonic uplift. Subsequent tectonics was due to a second accretion-collision.

\section{Structure of the Yili-North Tianshan domain}

\subsection{East Tianshan}

To the east of Urumqi (East Tianshan), NTS is separated into two branches by the Turfan-Hami (Tu-Ha) Basin (Figure 1). A southern one is in contact with CTS along the MTSZ and a northern one corresponds to Bogda that is now overthrusting onto the Junggar Basin toward the north and the Tu-Ha Basin toward the south [16, 23]. The Harlik 
Mountain, to the east of Bogda, is likely a part of the Mongolian Fold Belt instead of an eastern extension of the Bogda arc [16]. The structure of the southern branch is illustrated in the Toksun area (Figure 3), and that of the northern one reflected by the Bogda arc and has been already described [16]. All sections show a north-vergent deformation. Ductile microstructures are rare and many features are developed at a rather high structural level, near the ductile-brittle transition. The most common structures are folds, which are overlain by the Permian unconformity, as seen at the northern edge of Tu-Ha Basin [49]. The age of late normal faults, trending $80^{\circ}-110^{\circ} \mathrm{N}$ and dipping at $70^{\circ}-80^{\circ}$ northward or southward, cannot be determined. Normal faults almost perpendicular to the belt, that were accompanied by olistostrome formation and collapse tectonics [87], initiated during the Permian extension [48]. In summary, in the western part, a latest Carboniferous deformation was responsible for $\mathrm{N}$-verging folding and thrusting. This north-vergent deformation has essentially the characteristics of thin-skinned tectonics [16].

More to the east, near Yamansu (Figure 1), the Carboniferous sequence is composed of sedimentary rocks overlain by andesitic volcanic rocks and tuffs and unconformably covered by the Permian. A peculiar feature of this area is the occurrence of Early Permian intrusive mafic/ultramafic rocks that cross-cut the Upper Carboniferous Gandun Formation black shale and limestone. These rocks, incorrectly referred to as "ophiolites" in previous studies [88, 89], are actually layered intrusive complexes assigned to the Alaskean type and formerly interpreted either as relics of an intra-arc basin or as the last pulse of arc magmatism [37, 64, 90]. Actually these Early Permian intrusions (280 Ma U-Pb zircon [91], SHRIMP zircon $269.2 \pm 3.2$ and $277.0 \pm 1.6 \mathrm{Ma}$ [92]) post-date the north-directed deformation of the Carboniferous rocks, and are closely associated with Permian ductile strike-slip faults as indicated by their sigmoid shape. They also mark a change in the geotectonic setting after the Late Carboniferous-Early Permian tectonism [16, 87].

\subsection{West Tianshan}

Figure 7 summarizes the structure in the West Tianshan. To the north of NTF, a Carboniferous accretionary wedge is well developed, including trench-fill turbidites (Figure 4(d)) and the Bayingou ophiolitic mélange [26, 27, 28, 31] (Figure 4(e)). To the south of NTF, the Yili unit shows Upper Devonian-Carboniferous subduction-related volcanic sequences [26, 27, 28, 31, 39] and plutonic rocks [30, 93]. In some areas, like in the southern part close to the CTSZ, near Tekes for instance (Figure 6), the Carboniferous volcanic rocks directly overlie the Proterozoic basement (Sinian dolomite) and the Lower Paleozoic series is missing [31]. In the north, as near Sayram-Jinghe Fault (Figure 1), the Lower Paleozoic beds covers the Precambrian basement. The Yili unit extends westwards into Kazakhstan where it exhibits a complex structure [4]. The occurrence of several suture zones argues for a Lower Paleozoic polyphase assemblage of this block. In the westernmost part of Chinese Tianshan, one of this early suture zones of Cambrian-Early Ordovician age, is preserved near Xiate, in the southern border of Yili [94]. This likely infers that the Yili unit and the NTS pre-Carboniferous basement as a whole represent the eastern end of the composite Kazakhstan Block, amalgamated to Tarim Basin by the first accretion event. During the Carboniferous, the Yili unit was part of an active margin atop the amalgamated Tarim-CTS-NTS continent, with the volcanic chain to the south and the fore-arc domain on the northern border.

The tectonic structures are verging north, sealed by Permian intrusives, volcanic rocks, and red beds, and crosscut by the Permian strike-slip faults [27, 28, 31]. All these data strongly argue for a southward subduction of the NTS Ocean.

However, in CTS, some south-verging structures are assigned to this Late Carboniferous-Early Permian event [33], as in East Tianshan, confirming that the collision induced a kind of symmetrical fan-shaped bulk structure. The southdirected back-thrusts involved CTS and STS, the Tarim

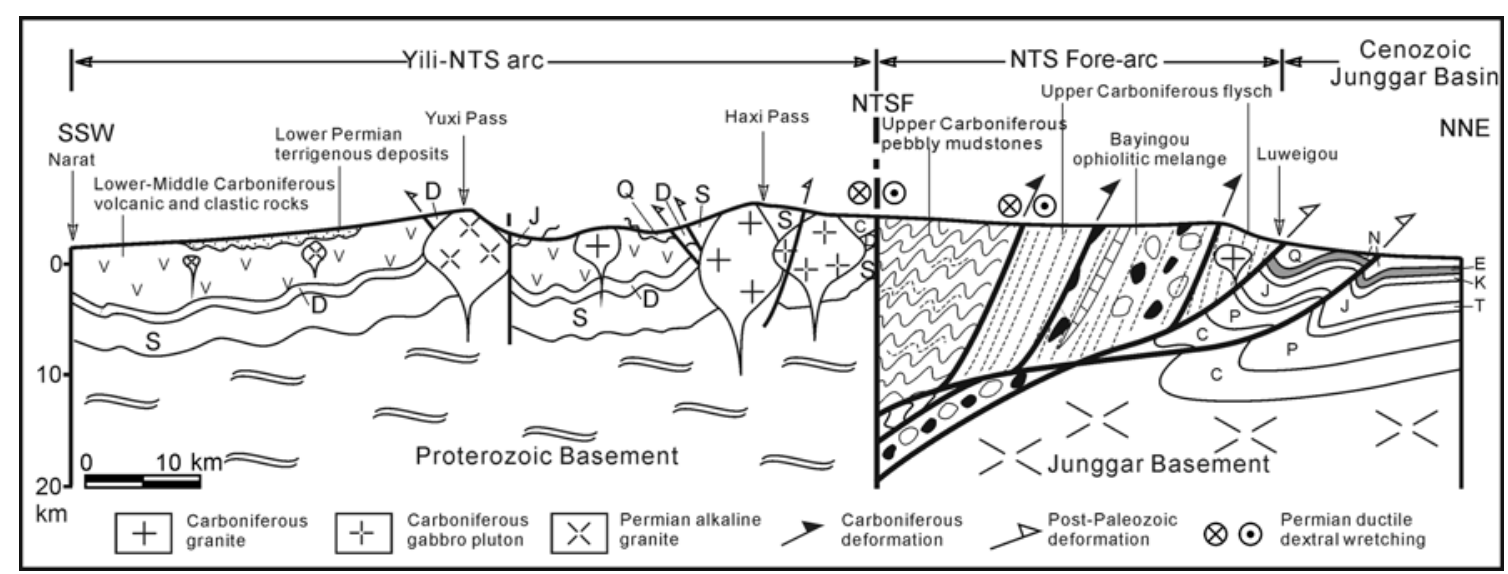

Figure 7 Cross-section of Yili-NTS (location on Figure 1). Modified after ref. [27]. 
Plate becoming at that time a relative foreland.

To the north of Sayram-Jinghe Fault (7 in Figure 1), the Bole area shows Devonian sandstone, Lower Carboniferous limestone and clastic series. The Carboniferous strata may overlie directly the Proterozoic basement, like in southern Yili unit, or rest disconformably upon Devonian clastics. Carboniferous arc-related volcanic rocks are reported near the Kazakhstan border and on the northwestern extension of this unit in Kazakhstan [4]. Therefore, the simplest assumption is to consider the Bole area as a piece of Yili unit offset by faults.

\subsection{Summary of the second tectonic event: the birth of the Paleozoic Tianshan}

An overall feature of pre-Permian tectonics of NTS volcanic arc and forearc is north-verging thrusting and folding, expressed in a more ductile fashion in the Yamansu-Huangshan area, decreasing in intensity westward and northward, but compatible with thin-skinned tectonics. In the southern part of Eo-Tianshan Mountains, this event induced symmetrical south-directed folding. It is better explained by the southward subduction of NTS ocean beneath the NTS arc, leading to collision with the Junggar Block.

\section{Discussion and geodynamic interpretation}

\subsection{Age and significance of suture zones}

The data presented above allow us to check the significance of the three suture zones described [16, 26, 31].

The oldest suture is the Devonian CTSZ, marked by the Gangou-Mishigou mélange and HP-UHP rocks (Koksu area and its westerly extension on the southern side of Narat Fault [26, 31]). It resulted from the closure of an oceanic domain located to the north (present coordinates) of the CTS arc, after a southward subduction starting in the Ordovician. The oceanic closure led to a northward thrusting of ophiolite and HP mélanges onto the NTS-Yili basement. At the beginning, the arc was located on the northern border of Tarim Plate.

The second one is the STSZ, root of the STS nappes of ophiolitic mélanges, corresponding to the closure of a STS back-arc basin, in the earliest Carboniferous. This back-arc basin was likely spreading during the Late Silurian and Devonian, on the northern edge of Tarim Plate, as suggested by the Silurian olistostromes on Tarim Plate [16], the increasing bathymetry recorded by the Devonian sequence in the southern part of CTS, and the Devonian radiometric ages of the ophiolitic rocks. Its closure was accommodated by a Late Devonian-Early Carboniferous southward subduction beneath the Tarim Plate, where it induced a subduction-related magmatism, subduction that led to northward obduction, and finally thrusting of Tarim units over the suture zone, as seen in Hongliuhe area [77].
These two suture zones resulted from one single southward subduction, initiated in the Ordovician, of the CTS Ocean beneath the Tarim Plate, which finally led to the Devonian to Early Carboniferous collision with the NTS-Yili unit (eastern extension of the Kazakhstan plate). Recently, a strip of Cambrian-Ordovician MORB-type basalts and adakitic diorites has been described in the southwesternmost Chinese Tianshan, near Xiate, and interpreted as a suture between CTS and STS [85, 94]. In our view, as this Ordovician suture is located to the north of the HP metamorphic unit underlining the CTSZ, and therefore within the Kazakhstan-Yili unit, it is more likely the eastern extension of the Kyrgyz-Terskey suture zone well developed within the Kazakhstan plate in Kyrgyzstan [4, 95]. It is truncated by the Narat Fault, which is not itself a suture zone and connects to the southwest with the Nikolaev Line [96]. In other words, it is a part of the Kazakhstan-Yili Plate building history, which was completed prior to its collision with CTS arc.

The last suture zone in Tianshan is the NTSZ [16, 26, 31]. Easily inferred in West Tianshan, where the Bayingou mélanges are exposed, it is supposed to continue beneath the Cenozoic northward thrust of Bogda over Junggar Basin, although only turbidites are exposed on the northern foot of Bogda. This hypothesis is supported by the fact that in the Late Carboniferous paleogeography, before the Tu-Ha Basin opening, the Bogda arc was more to the south, almost aligned with the Bayingou unit. The age, according to the stratigraphic constraints, is Late Carboniferous to Early Permian. It is due to the southward subduction of a NTS Ocean, responsible for the Yili-NTS arc, leading to collision with the Junggar Block, whose nature is unclear although likely a buoyant feature $[16,26,27]$. A northward subduction is implausible: the Bayingou accretionary wedge indicates a location of the Carboniferous forearc on the northern side of NTS; to the south, as the CTSZ closed in the Devonian, there was no more ocean to be consumed in the Carboniferous; lastly, the northern vergence of structures is in agreement with a former southward dip of the subduction plane.

Before the Middle Permian, and maybe some Early Permian, all the units from Junggar to Tarim were amalgamated. Their further evolution was intracontinental, marked by post-collisional magmatism, olistostrome formation, and strike-slip shearing [9, 12, 13, 16, 87].

\subsection{A geodynamic model}

Four main colliding blocks are considered in our model (Figure 8): the Tarim, CTS, Yili-NTS continental blocks, and the Junggar. They are assumed to have a buoyant lithosphere, but the nature of which (micro-continent, arc?) is still debated.

A CTS Ocean subduction beneath the Tarim active margin began during the Ordovician. The CTS island arc was 
(a) Ordovician-Silurian

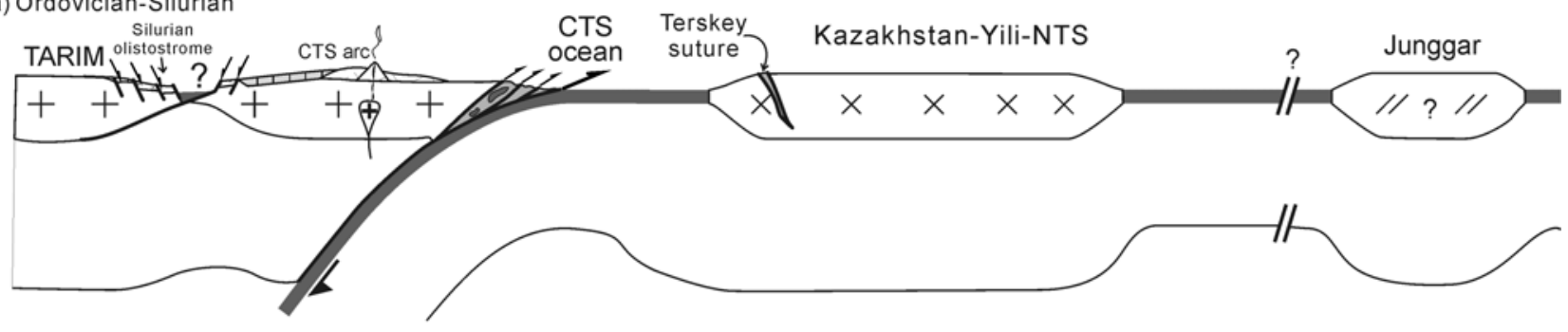

(b) Middle-Late Devonian
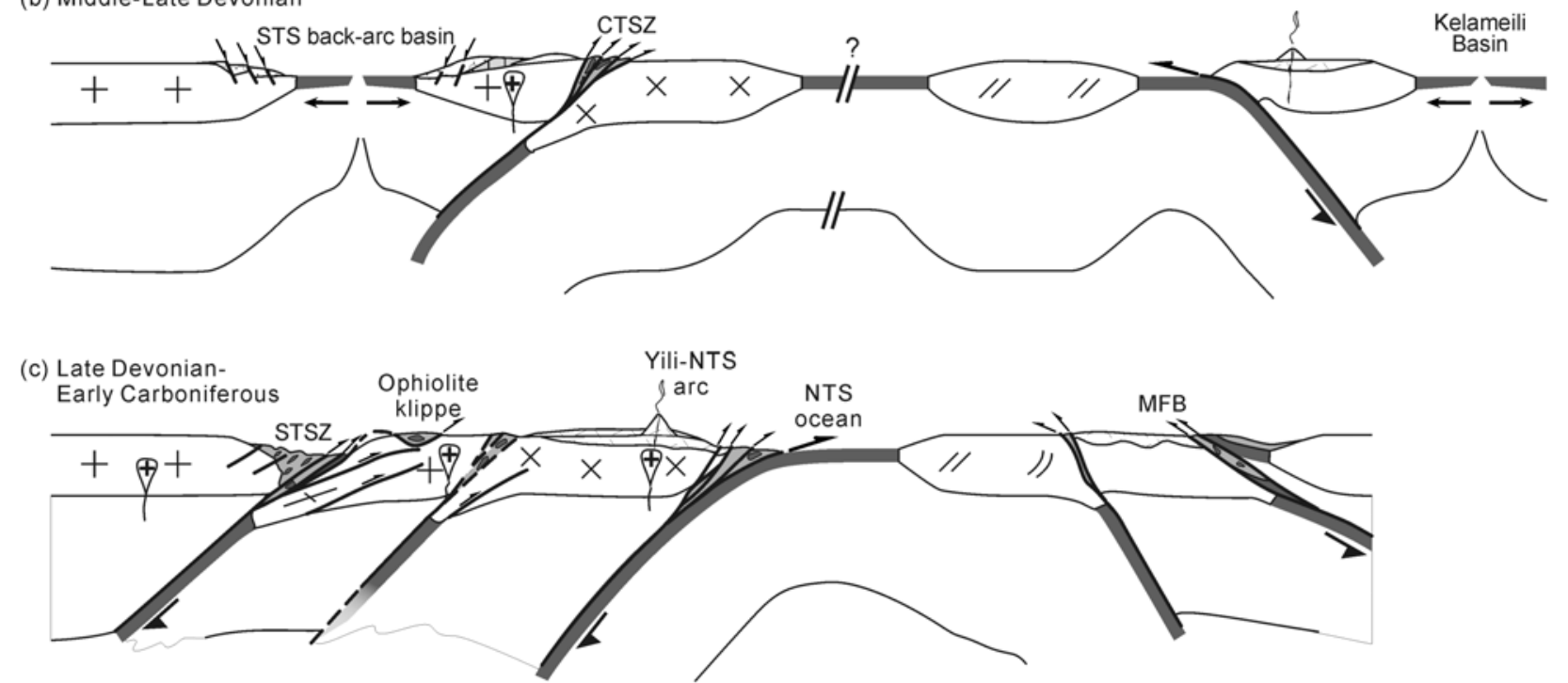

(d) Late Carboniferous Carboniferous

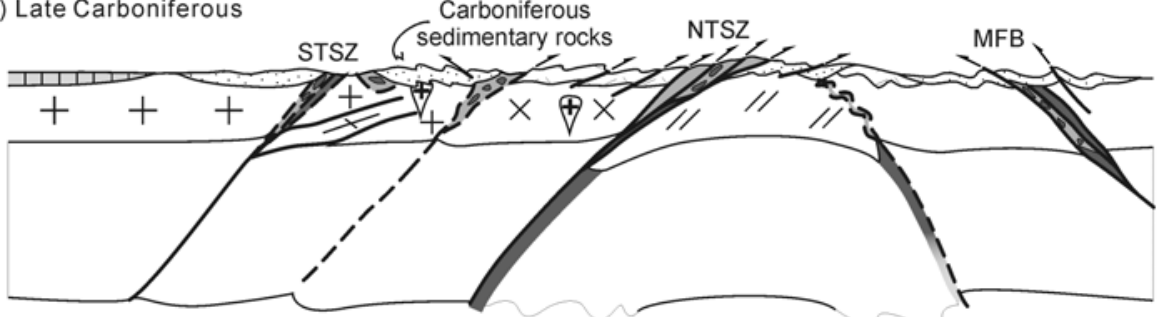

Figure 8 Schematic geodynamic evolutionary model of Chinese Tianshan. CTS-Central Tianshan; NTS-North Tianshan; CTSZ-Central Tianshan Suture Zone; NTSZ-North Tianshan Suture Zone; STSZ-South Tianshan Suture Zone; MFB- Mongolian Fold Belt. Modified after ref. [16].

detached, following Silurian rifting of northern Tarim, opening of the STS back-arc basin during the Late Silurian-Devonian (Figure 8(a)). In the southern part of the Kazakhstan-Yili Block, the Terskey suture took place likely in the Middle Ordovician.

In the Late Devonian, CTS Ocean closure led to the collision of Yili-NTS Block with CTS, responsible for the CTSZ (Figure 8(b)). During the Late Devonian-earliest Carboniferous, the subsequent STS back-arc basin closure induced the STSZ, with northward ophiolite obduction, and the docking of CTS-Yili onto Tarim, building the Eo-Tianshan (Figure 8(c)). A new subduction zone was initiated on the northern edge of this domain, as the NTS Ocean began to subduct southward in the Late Devonian, inducing the NTS volcanic arc and the NTS accretionary complex. The closure of the NTS Ocean led to the collision between Junggar Block and NTS at the end Carboniferous (Figure 8(d)). By the Early-Middle Permian, all the blocks from Tarim to Junggar, and even to Siberia $[16,97]$ were amalgamated. Intracontinental wrench tectonics then began (Figure 9), accompanied by opening of pull-apart basins, alkaline magmatism, and red molasse accumulation [27, 48, 87]. A huge strike-slip tectonics accommodated an opposite motion of Siberia and Tarim [97, 98]. The two blocks Yili-NTS and Junggar, linked since the Late Carboniferous [97], moved eastward with respect to Siberia and Tarim, along the sinistral Erqishi fault system to the north and the dextral Permian shear zones in Tianshan. Their eastward motion relative to Tarim was in the scale of hundreds of kilometres during the Permian [97].

The Eo-Tianshan building gathers the main characteristics of a collisional orogen: ophiolites, HP metamorphic 
(a) Late Carboniferous-Early Permian
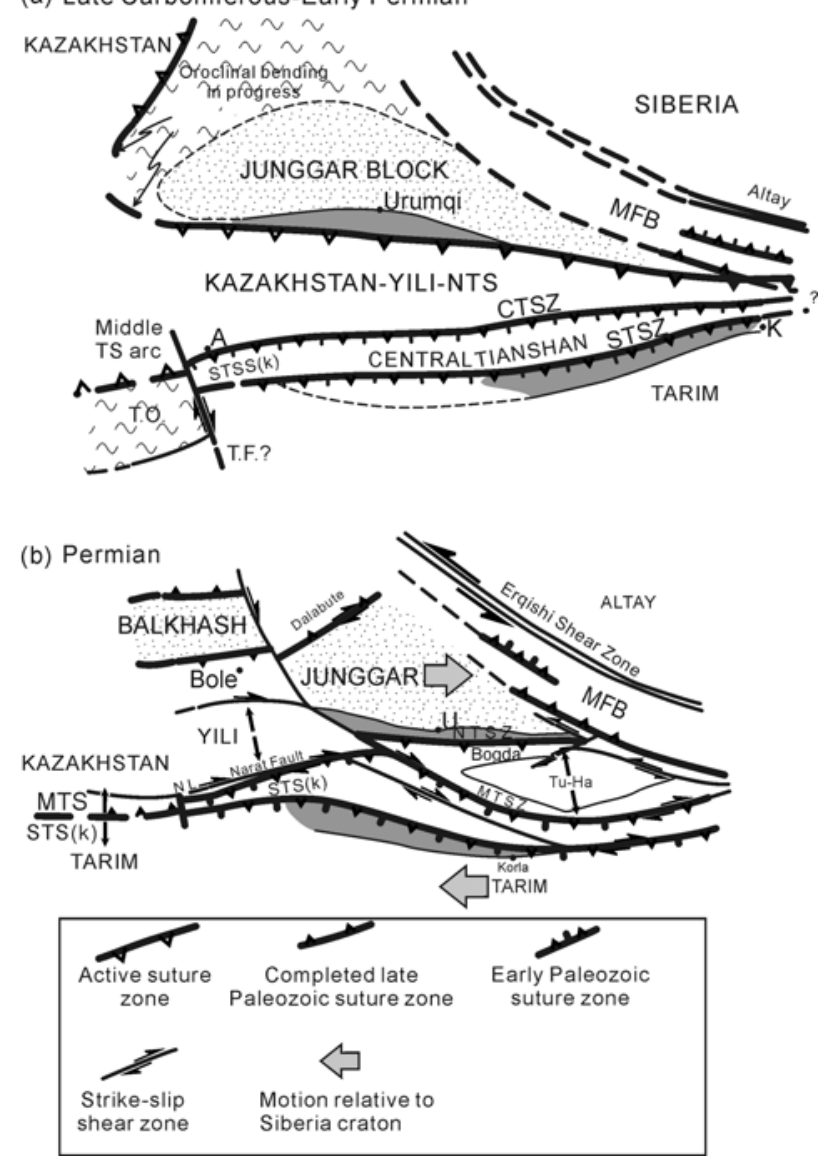

Figure 9 Map-view cartoon showing the evolution of main units and suture zones around Junggar from Late Carboniferous to Late Permian, and the correlations with Kazakh and Kyrgyz Tianshan. (a) Late Carboniferous-Early Permian closure of Central Asian Ocean along the NTSZ by overthrusting of Yili-NTS onto the Junggar Block, evolution of the Kazakhstan orocline; northward subduction (before Moscovian) of the Turkestan Ocean beneath Yili-Kazakhstan plate to the west of Eo-Tianshan. (b) Rearrangement of units due to the Permian wrenching, accompanied by opening of Yili and Tu-Ha basins. Completion of the Kazakh orocline. Shaded areas represent the zones consumed during Cenozoic intra-continental subduction of Junggar and Tarim plates. NL-Nicolaev Line; TO-Turkestan Ocean; A-Atbashi; K-Korla; U-Urumqi; MTS, STS (K), STTS (K)-Middle Tianshan, South Tianshan, and South Tianshan Suture in Kyrgyz Tianshan.

rocks, granites, post-collisional magmatism and uplift, and the continental nature of Tarim and Yili-NTS colliding blocks. It is less clear for the second event, especially because the nature of Junggar basement is debated, either oceanic [99, 100] or continental [101, 102]. However, the type of Permian post-tectonic magmatism strongly suggests a prominent contribution of the asthenosphere $[32,93]$. This implies either a ridge subduction leading to a slab window [4] or a slab break-off after collision. We prefer the latter hypothesis, which better explains the widespread compressive tectonism including the back thrusting induced in CTS and STS [103, 104]. But the underthrusting of the buoyant Junggar Block likely remained limited. The reason for that, maybe linked to an oblique subduction-collision in relation to the Kazakhstan orocline bending, is unclear.

\subsection{Correlation with the Kazakh and Kyrgyz Tianshan}

Figure 9 shows a possible Late Carboniferous to Late Permian evolution of the Junggar-Tarim region. The Bole unit is assumed to be part of the Yili-Kazakhstan Block, as suggested by its stratigraphical features and the existence of a Carboniferous arc to the north [4]. The northern part of Yili-NTS continues to Kazakhstan where the Junggar-Balkash Suture Zone is the western extension of the NTSZ [4, 105]. Due to the Kazakhstan orocline [4, 106, 107] the Dalabut suture zone, to the west of Junggar Basin, could represent the bent extension of NTSZ. A correlation further east with Kelameili, suggested by the geometry, is unlikely, as the Tuvaella fauna, specific of peri-Siberian units [108], is present in east Junggar down to Barkol area [109].

Anyway, the NTSZ is the youngest suture of the Chinese Tianshan. The hypothesis of a Late Permian or even a Triassic oceanic domain in western STS, based on zircon dating [38] and controversial radiolarian fauna [110] which was in contradiction with regional geology [16], can now be ruled out $[32,34]$. Therefore, the NTSZ, with its possible westward and eastward extensions, is the last trace of the Central Asian Ocean.

In Kyrgyzstan, the North Tianshan, equivalent of the Kazakhstan-Yili-NTS Block as described here, is bounded to the south by the Nikolaev Line [96], which reworks the Kyrgyz-Terskey suture zone running on its northern side [111], and connects eastward with the Narat Fault in China $[29,34,94]$. To the south of it, stands the Middle Tianshan [112], bounded by the Atbashi-Inylchek Fault. The latter joins the Nikolaev-Narat Fault close to the border. So, the Middle Tianshan thins out toward the east $[113,114]$. The CTSZ is the eastern extension in China of the so-called South Tianshan Suture Zone in Kyrgyzstan, and the Chinese CTS and STS all together correspond to the Kyrgyz South Tianshan [112]. However, a main discrepancy is apparent in the literature, regarding the timing and the kinematics, as authors argue for an active margin at the southern edge of the Kazakhstan Plate in the Kyrgyz Tianshan during the Devonian-Carboniferous and a Late Carboniferous southward obduction and collision $[115,116]$ following a northward subduction of a Turkestan ocean [112, 114, 117, 118]. But, recent observations of the senior author in Kyrgyzstan allow us to reconcile the two different interpretations. East of the Talas-Ferghana Fault, there is no Carboniferous volcanic arc in Middle Tianshan, unlike the western side where a huge arc is developed [114]. Moreover, new datings of the Atbashi suture ophiolites give a Devonian age instead of a Late Carboniferous one [119] and, finally, our observations suggest an initial northward emplacement of these ophiolites. All those elements support the correlation between the Gangou-Mishigou-Koksu Suture Zone and the Atbashi one, and the timing and kinematics become similar. In addition, 
to the south of Atbashi, some other ophiolitic units are reported [120] in a position equivalent to the Kumux ones.

Therefore, in Figure 9 we retain the possibility of a different evolution of the eastern and western branches of South Tianshan. In the west, an oceanic domain remained open after the Yili-CTS collision, and closed in the Late Carboniferous. The transition could be accommodated by a transform fault (Figure 9). The recent Talas-Ferghana Fault may have re-used this transverse discontinuity. It is worth to note that it marks the western end of Tarim. In other words, the early-middle Paleozoic evolution explained in this paper records the convergence history between the Kazakhstan and Tarim plates, valid also in the eastern Kyrgyz Tianshan. To the west, a different evolution was linked to the docking of other blocks: the Alai and Turan ones.

\section{Conclusions}

The Chinese Tianshan provides clues to the mode of accretion in the southern CAOB.

(1) A first accretion-collision stage built the Eo-Tianshan Mountains before the Visean. After a southward subduction of a CTS ocean beneath the Tarim active margin including a STS back-arc basin, the collision between Tarim and Yili-NTS continental blocks produced the CTSZ and STSZ, north-verging thrust sheets of ophiolitic mélanges and HP/ UHP metamorphic rocks, followed by post-tectonic magmatism, uplift, and erosion. The Eo-Tianshan was a rather typical collisional orogen.

(2) A second accretion-collision stage was due to the Late Carboniferous-Early Permian collision of the EoTianshan with Junggar Block after a NTS ocean southward subduction beneath the Eo-Tianshan active margin. This collision induced north-directed deformation in NTS, and symmetrical south-directed deformation in CTS and STS. The Permian post-collisional magmatism suggests a slab break off, and the low subsequent uplift argues for a limited underthrusting of a Junggar buoyant unit.

(3) The NTSZ is likely the last trace of the Central Asian Ocean in this area, the last suture of CAOB, which was completed before Early-Middle Permian.

(4) During the Permian, all the units already amalgamated experienced a major wrenching, dextral in Tianshan, accommodating the opposite motion of Siberia and Tarim.

(5) A different evolution known in the Kyrgyz Tianshan may be due to a geodynamic scenario in two steps regarding the southern border of Kazakhstan-Yili plate: the Eo-Tianshan orogeny involved only its eastern part, leaving an open ocean to the west; this Turkestan ocean closed later, during the Late Carboniferous, by a northward subduction. After the collision, the Permian wrenching drifted the Tarim relatively westwards to more or less its present position.
Anonymous reviewers are gratefully acknowledged for their generous helps to improve the manuscript. This study was financially supported by National Basic Research Program of China (Grant No. 2007CB411301), the Bureau of China Geological Survey (Grant No. 1212010611806), and ISTO.

1 Sengör A M C, Natal'in B A, Burtman V S. Evolution of the Altaid tectonic collage and Paleozoic crust growth in Eurasia. Nature, 1993, 364: 299-307

2 Natal'in B A, Sengör A M C. Late Palaeozoic to Triassic evolution of the Turan and Scythian platforms: The pre-history of the PalaeoTethyan closure. Tectonophysics, 2004, 404: 175-202

3 Xiao W J, Windley B F, Bardach G, et al. Palaezoic accretionary and convergent tectonics of the southern Altaids: Implications for the growth of Central Asia. J Geol Soc London, 2004, 161: 339-342

4 Windley B F, Alexeiev D, Xiao W J, et al. Tectonic models for accretion of the Central Asian Orogenic Belt. J Geol Soc London, 2007, 164: $31-47$

5 Coleman R G. Continental growth of northwest China. Tectonics, 1989, 8: 621-635

6 Windley B F, Allen M B, Zhang C, et al. Paleozoic accretion and Cenozoic redeformation of the Chinese Tien Shan range, Central Asia. Geology, 1990, 18: 128-131

7 Allen M B, Windley B F, Zhang C. Paleozoic collisional tectonics and magmatism of the Chinese Tien Shan, Central Asia. Tectonophysics, 1992, 220: 89-115

8 Berzin N, Coleman R G, Dobretsov N L, et al. Geodynamic map of the western part of the Paleoasian ocean. Russian Geol Geophys, 1994, 35: 5-22

9 Shu L S, Charvet J, Guo L Z, et al. A large-scale Palaeozoic dextral ductile strike-slip zone: The Aqqikkudug-Weiya zone along the northern margin of the Central Tianshan belt, Xinjiang, NW China. Acta Geol Sin, 1999, 73: 148-162

10 Shu L S, Charvet J, Lu H F, et al. Paleozoic accretion-collision events and kinematics of ductile deformation in the central-southern Tianshan Belt, China. Acta Geol Sin, 2002, 76: 308-323

11 Laurent-Charvet S. Accrétions continentales en Asie centro-orientale: évolution géodynamique et structurale du Tianshan et du Junggar oriental (nord-ouest Chine) au Paléozoïque, Ph. D Dissertation, University of Orléans, Orléans, France, 2001. 1-312

12 Laurent-Charvet S, Charvet J, Shu L S, et al. Palaeozoic late collisional strike-slip deformations in Tianshan and Altay, eastern Xinjiang, NW China. Terra Nova, 2002, 14: 249-256

13 Laurent-Charvet S, Charvet J, Shu L S. Middle and Late Palaezoic northward deformations in Tianshan (NW China): New structural insights along field cross-sections in South, Central and North Tianshan units. IGCP 480 Meeting, Irkutsk, 25-27 July, 2005. 234-239

14 Charvet J, Laurent-Charvet S, Shu L S, et al. Paleozoic continental accretions in Central Asia around Junggar Block: New structural and geochronological data. Gondwana Res, 2001, 4: 590-592

15 Charvet J, Laurent-Charvet S, Shu L S, et al. Paleozoic geodynamic evolution of Tianshan orogenic belt (NW China): Welding of Tarim and Junggar continental blocks. In: Symposium G05-09 Tethys Reconstruction, Abstract, 2004. 155

16 Charvet J, Shu L S, Laurent-Charvet S. Paleozoic structural and geodynamic evolution of eastern Tianshan (NW China): Welding of the Tarim and Junggar plates. Episodes, 2007, 30: 162-186

17 Molnar P, Tapponnier P. Cenozoic tectonics of Asia: Effects of a continental collision. Science, 1975, 189: 419-426

18 Ren J S, Jiang C F, Zhang Z K, et al. Geotectonic evolution of China. Beijing, Springer Verlag, Berlin-Heidelberg: Science Press, 1987. $1-203$

19 Avouac J P, Tapponnier P. Kinematic model of active deformation in Central Asia. Geophys Res Lett, 1993, 20: 895-898

20 Hendrix M S, Dumitru T A, Graham S A. Late Oligocene-Early Miocene unroofing in the Chinese Tian Shan: An early effect of the India-Asia collision. Geology, 1994, 22: 487-490

21 Lu H F, Howell D G, Jia D, et al. Kalpin transpression tectonics, 
Northwestern Tarim Basin, Western China. Int Geol Rev, 1994, 36: 975-981

22 Allen M B, Vincent S J, Wheeler P J. Late Cenozoic tectonics of the Kepingtage thrust zone: Interactions of the Tien Shan and Tarim Basin, northwest China. Tectonics, 1999, 18: 639-654

23 Burchfiel B C, Brown E T, Deng Q D, et al. Crustal shortening on the Margins of the Tien Shan, Xinjiang, China. Int Geol Rev, 1999, 41: 665-700

24 Poupinet G, Avouac J P, Jiang M, et al. Intracontinental subduction and Palaeozoic inheritance of the lithosphere suggested by a teleseismic experiment across the Chinese Tien Shan. Terra Nova, 2002, 14: $18-24$

25 Wang C Y, Yang Z E, Luo H, et al. Crustal structure of the northern margin of the eastern Tien Shan, China, and its tectonic implications for the $1906 \sim M 7.7$ Manas earthquake. Earth Planet Sci Lett, 2004, 223: 187-202

26 Wang B. Evolution géodynamique du Bloc de Yili (nord-ouest Chine) au Paléozoïque. PhD Dissertation. Universities of Nanjing and Orléans, 2006. 1-231

27 Wang B, Faure M, Cluzel D, et al. Late Paleozoic tectonic evolution of the northern West Chinese Tianshan Belt. Geodin Acta, 2006, 19: 237-247

28 Wang B, Shu L S, Faure M, et al. Geochemical constraints on Carboniferous volcanic rocks of Yili Block (Xinjiang, NW China): Implications on tectonic evolution of Western Tianshan. J Asian Earth Sci, 2007, 29: 148-159

29 Wang B, Shu L S, Faure M, et al. Paleozoic tectonism and magmatism of Kekesu-Qionkushitai section in southwestern Chinese Tianshan and their constraints on the age of the orogeny. Acta Petrol Sin, 2007, 23: 1354-1368

30 Wang B, Shu L S, Cluzel D, et al. Geochronological and geochemical studies on the Borohoro plutons, north of Yili, NW Tianshan and their tectonic implication. Acta Petrol Sin, 2007, 23: 1885-1900

31 Wang B, Faure M, Shu L S, et al. Paleozoic tectonic evolution of the Yili Block, Western Chinese, Tianshan. Bull Soc Géol France, 2008, 179: 483-490

32 de Jong K, Wang B, Faure M, et al. New ${ }^{40} \mathrm{Ar} /{ }^{39} \mathrm{Ar}$ age constraints on Late Palaezoic tectonic evolution of the western Tianshan (Xinjiang, northwestern China), with emphasis on Permian fluid ingress. Int J Earth Sci, 2008, doi: 10.1007/s00531-008-0338-8

33 Lin W, Faure M, Shi $\mathrm{Y} \mathrm{H}$, et al. Palaeozoic tectonics of the south-western Chinese Tianshan: New insights from a structural study of the high-pressure/low temperature metamorphic belt. Int $\mathbf{J}$ Earth Sci, 2008, doi: 10.1007/s00531-008-0371-7

34 Gao J, Long L L, Klemd R, et al. Tectonic evolution of the South Tianshan orogen and adjacent regions, NW China: Geochemical and age constraints of granitoid rocks. Int J Earth Sci, 2009, 98: $1221-1238$

35 Laurent-Charvet $\mathrm{S}$, Charvet J, Monié $\mathrm{P}$, et al. Late Paleozoic strike-slip shear zones in eastern Central Asia (NW China): New structural and geochronological data. Tectonics, 2003, 22: 1099-1101

36 Gao J, Li M S, Xiao X C, et al. Paleozoic tectonic evolution of the Tianshan orogen, northwestern China. Tectonophysics, 1998, 287: 213-231

37 Xiao W J, Zhang L C, Qin K Z, et al. Paleozoic accretionary and collisional tectonics of the eastern Tianshan (China): Implications for the continental growth of Central Asia. Am J Sci, 2004, 304: 370-395

38 Zhang L F, Ai Y L, Li X P, et al. Triassic collision of western Tian-shan orogenic belt, China: Evidence from SHRIMP U-Pb dating of zircon from HP/UHP eclogitic rocks. Lithos, 2007, 96: 266-280

39 Zhu Y F, Zhang L F, Gu L B, et al. The zircon SHRIMP chronology and trace element geochemistry of the Carboniferous volcanic rocks in western Tianshan Mountains. Chin Sci Bull, 2005, 50: 2201-2212

40 Zhai W, Sun X M, Gao J, et al. SHRIMP dating of zircons from volcanic host rocks of Dahalajunshan Formation in Axi gold deposit, Xinjiang, China, and its geological implications (in Chinese with
English abstract). Acta Petrol Sin, 2006, 22: 1399-1404

41 Xinjiang Bureau of Geology and Mineral Resources. Regional Geology of Xinjiang Uygur Autonomous Region (in Chinese with English abstract). Beijing: Geological Publishing House, 1993. 1-841

42 Chen C M, Lu H F, Jia D, et al. Closing history of the southern Tianshan oceanic basin, western China: An oblique collisional orogeny. Tectonophysics, 1999, 302: 23-40

43 Carroll A R. Late Palaeozoic tectonics, sedimentation, petroleum potential of the Junggar and Tarim Basins, Northwest China. PhD Dissertation. Stanford: Stanford University, 1991. 1-405

44 Xiao X C, Tang Y Q, Feng Y M, et al. Tectonic Evolution of the Northern Xinjiang and Its Adjacent Regions. Beijing: Geological Publishing House, 1992. 1-190

$45 \mathrm{Xu} \mathrm{X} \mathrm{Y,} \mathrm{Ma} \mathrm{Z} \mathrm{P,} \mathrm{Xia} \mathrm{L} \mathrm{Q,} \mathrm{et} \mathrm{al.} \mathrm{SHRIMP} \mathrm{dating} \mathrm{of} \mathrm{plagiogranite}$ from Bayingou ophiolite in the northern Tianshan Mountains (in Chinese with English abstract). Geol Rev, 2005, 51: 523-527

$46 \mathrm{Xu} \mathrm{X} \mathrm{Y,} \mathrm{Li} \mathrm{X} \mathrm{M,} \mathrm{Ma} \mathrm{Z} \mathrm{P,} \mathrm{et} \mathrm{al.} \mathrm{LA-ICPMS} \mathrm{zircon} \mathrm{U-Pb} \mathrm{dating} \mathrm{of}$ gabbro from the Bayingou Ophiolite in the northern Tianshan Mountains (in Chinese with English abstract). Acta Geol Sin, 2006, 80: $1168-1176$

47 Xia L Q, Xu X Y, Xia Z C, et al. Petrogenesis of Carboniferous rift-related volcanic rocks in the Tianshan, northwestern China. Geol Soc Am Bull, 2004, 116: 419-433

48 Shu L S, Chen Y T, Lu H F, et al. Paleozoic accretionary terranes in Northern Tianshan, NW China. Chin J Geochem, 2000, 19: 193-202

49 Wartes M A, Carroll A R, Greene T J. Permian sedimentary record of the Turpan-Hami basin and adjacent regions, Northwest China: Constraints on postamalgamation tectonic evolution. Geol Soc Am Bull, 2002, 114: 131-152

$50 \mathrm{Hu} \mathrm{A} \mathrm{Q}$, Zhang G X, Zhang Q F, et al. Constraints on the age of basement and crustal growth in Tianshan orogen by $\mathrm{Nd}$ isotope composition. Sci China Ser D-Earth Sci, 1998, 41: 648-657

51 Hu A Q, Jahn B M, Zhang G X, et al. Crustal evolution and Phanerozoic crustal growth in northern Xinjiang: $\mathrm{Nd}$ isotopic evidence. Part I. Isotopic characterization of basement rocks. Tectonophysics, 2000, 328: 15-51

52 Liu S W, Guo Z J, Zhang Z C, et al. Nature of the Precambrian metamorphic blocks in the eastern segment of Central Tianshan: Constraints from geochronology and Nd isotopic geochemistry. Sci China Ser D-Earth Sci, 2004, 47: 1085-1094

53 Zhu Y F, Song B. Petrology and SHRIMP chronology of mylonitized Tianger granite, Xinjiang: Also about the dating on hydrothermal zircon rim in granite (in Chinese with English abstract). Acta Petrol Sin, 2006, 22: 135-144

54 Li Q G, Liu S W, Wang Z Q, et al. Geochemical constraints on the petrogenesis of the Proterozoic granitoid gneisses from the eastern segment of the Central Tianshan tectonic zone, northwestern China. Geol Mag, 2007, 144: 305-317

55 Yang T N, Wang Y, Li J Y, et al. Vertical and horizontal strain partitioning of the Central Tianshan (NW China): Evidence from structures and ${ }^{40} \mathrm{Ar} /{ }^{39} \mathrm{Ar}$ geochronology. J Str Geol, 2007, 29: 1605-1621

56 Li Q G, Liu S W, Wang Z Q, et al. Electron microprobe monazite geochronological constraints on the Late Palaeozoic tectonothermal evolution in the Chinese Tianshan. J Geol Soc, 2008, 165: 511-522

$57 \mathrm{Xu} \mathrm{X} \mathrm{Y,} \mathrm{Ma} \mathrm{Z} \mathrm{P,} \mathrm{Xia} \mathrm{Z} \mathrm{C,} \mathrm{et} \mathrm{al.} \mathrm{TIMS} \mathrm{U-Pb} \mathrm{isotopic} \mathrm{dating} \mathrm{and}$ geochemical characteristics of Paleozoic granitic rocks from the middle-western section of Tianshan, Northwestern China (in Chinese with English abstract). Geology, 2006, 39: 50-75

58 Yang T N, Li J Y, Sun G H, et al. Earlier Devonian active continental arc in Central Tianshan: Evidence of geochemical analyses and zircon SHRIMP dating on mylonitized granitic rocks (in Chinese with English abstract). Acta Petrol Sin, 2006, 22: 41-48

59 Shi Y R, Liu D Y, Zhang Q, et al. SHRIMP zircon U-Pb dating of the Gangou granitoids, Central Tianshan Mountains, Northwest China and tectonic significances. Chin Sci Bull, 2007, 52: $1507-1516$

60 Carroll A R, Graham S A, Hendrix M S, et al. Late Paleozoic tectonic amalgamation of NW China: Sedimentary records of the north- 
northern Tarim, northwestern Turpan, and southern Junggar basins. Geol Soc Am Bull, 1995, 107: 571-594

61 Che Z C, Jiang K Y, Liu H F, et al. The establishment and geological significance of the Mid-Tianshan tectogenesis (in Chinese with English abstract). Geosci Xinjiang, 1993, 4: 51-58

62 Guo J, Shu L S, Charvet J, et al. Geochemical features of the two Early Paleozoic ophiolitic zones and volcanic rocks in the Central-Southern Tianshan Region, Xinjiang. Chin J Geochem, 2002, 21: 308-321

63 Shu L S, Yu J H, Charvet J, et al. Geological, geochronological and geochemical features of granulites in the Eastern Tianshan, NW China. J Asian Earth Sci, 2004, 24: 25-41

64 Ma R S, Wang C Y, Ye S F. Tectonic Framework and Crustal Evolution of Eastern Tianshan Mountains (in Chinese). Nanjing: Publishing House of Nanjing University, 1993. 1-225

65 Gao J, He G Q, Li M S, et al. The mineralogy, petrology, metamorphic PTDt trajectory and exhumation mechanism of blueschists, south Tianshan, northwestern China. Tectonophysics, 1995, 250: $151-168$

66 Gao J, Zhang L, Liu S. The ${ }^{40} \mathrm{Ar} /{ }^{39} \mathrm{Ar}$ age record of formation and uplift of the blueschists eclogites in the western Tianshan Mountains. Chin Sci Bull, 2000, 45: 1047-1051

67 Gao J, Klemd R. Formation of HP-LT rocks and their tectonic implications in the western Tianshan Orogen, NW China: Geochemical and age constraints. Lithos, 2003, 66: 1-22

68 Klemd R, Bröcker M, Hacker B R, et al. New age constraints on the metamorphic evolution of the highpressure/ low-temperature belt in the western Tianshan mountains, NW China. J Geol, 2005. 113: $157-168$

69 Zhu B Q, Feng Y M, Yang J L, et al. Discovery of ophiolitic mélange and Silurian foreland basin at Gangou of Tokxun, Xinjiang and their tectonic significance (in Chinese with English abstract). Xinjiang Geol, 2002, 20: 326-330

70 Wang B Y, Lang Z, Li X, et al. Comprehensive survey of geological sections in the west Tianshan of Xinjiang, China. Beijing: Science Press, 1994. 1-202

71 Liu B, Qian Y. The geological characteristics and fluid evolution in the three high-pressure metamorphic belts of eastern Tianshan (in Chinese with English abstract). Acta Geol Petrol, 2003, 19: 283-296

72 Wang J L, Wang R S, Zhou D W, et al. Variscan terrane of deep-crustal granulite facies in Yushugou area, southern Tianshan. Sci China Ser D-Earth Sci, 1999, 42: 482-490

73 Liu Y, Hao S G. Evolutionary significance of Pylentonemid Radiolarians and their Late Devonian species from southwestern Tianshan, China. Acta Geol Sin, 2006, 80: 647-655

74 Shu L S, Wang B, Zhu W B. Age and tectonic significance of radiolarian fossils from the Heiyingshan ophiolitic melange, southern Tianshan belt, NW China (in Chinese with English abstract). Acta Geol Sin, 2007, 81: 1-8

75 Zhou D W, Su L, Jian P, et al. Zircon U-Pb SHRIMP ages of Yushugou ophiolitic terrane in Southern Tianshan and their tectonic implications. Chin Sci Bull, 2004, 49: 1415-1419

76 Dong Y P, Zhou D W, Zhang C L, et al. Tectonic setting of the Wuwamen ophiolite at the southern margin of Middle Tianshan Belt (in Chinese with English abstract). Acta Petrol Sin, 2005, 21: 37-44

77 Jiang C Y, Mu Y M, Zhao X N, et al. Petrology and geochemistry of the intrusion belt along the northern active margin of the Tarim Plate (in Chinese with English abstract). Reg Geol China, 2001, 20: $158-163$

78 Zhu Z X. The geological components and tectonic evolution of South Tianshan, Xinjiang. PhD Dissertation. Beijing: Chinese Academy of Geological Sciences, 2007. 1-210

79 Hu A Q, Zhang G X, Zhang Q F. The basement age of Tianshan belt and the $\mathrm{Nd}$ isotopic constraining on crustal accretion. Sci China Ser D-Earth Sci, 1999, 20: 104-112

80 Han B F, He G Q, Li H M. Zircon U-Pb dating and geochemical features of Early Paleozoic granites from Tianshan, Xinjiang: Implications for tectonic evolution (in Chinese with English abstract). Xinjiang Geol, 2004, 22: 4-11
81 Rong J Y, Chen X, Su Y Z, et al. Silurian paleogeography of China. New York State Museum Bull, 2003, 493: 243-298

82 Chen Y B, Hu A Q, Zhang G X, et al. Precambrian basement age and characteristics of Southwestern Tianshan: Zircon U-Pb geochronology and Nd-Sr isotopic composition (in Chinese with English abstract). Acta Petrol Sin, 2000, 16: 91-98

83 Chen Y B, Hu A Q, Zhang G X, et al. Zircon U-Pb age of granitic gneiss in Duku highway in western Tianshan of China and its geologic implications. Chin Sci Bull, 2000, 45: 649-653

84 Long L L, Gao J, Xiong X M, et al. The geochemical characteristics and the age of the Kule lake ophiolite in the southern Tianshan. Acta Petrol Sin, 2006, 22: 65-73

85 Wei C J, Powell R, Zhang L F. Eclogites from the south Tianshan, NW China: Petrological characteristic and calculated mineral equilibria in the $\mathrm{Na}_{2} \mathrm{O}-\mathrm{CaO}-\mathrm{FeO}-\mathrm{MgO}-\mathrm{Al}_{2} \mathrm{O}_{3}-\mathrm{SiO}_{2}-\mathrm{H}_{2} \mathrm{O}$ system. J Metamorph Geol, 2003, 21: 163-179

86 Simonov V A, Sakiev K S, Volkova N I, et al. Conditions of formation of the Atbashi Ridge eclogites. Russian Geol Geophys, 2008, 49: 803-815

87 Shu L S, Zhu W B, Wang B, et al. The postcollision intracontinental rifting and olistostrome on the southern slope of Bogda Mountains, Xinjiang (in Chinese with English abstract). Acta Petrol Sin, 2005, 21: $25-36$

88 Ji J S, Li H Q, Zhang L C. Sm-Nd and Rb-Sr isotopic ages of magnetite-chlorite formation gold deposit in the volcanic rock area of Late Paleozoic Era, East Tianshan. Chin Sci Bull, 1999, 44: 1801-1804

89 Zhou J Y, Cui B F, Xiao H L, et al. The Kangguertag-Huangshan collision zone of bilateral subduction and its metallogenic model and prognosis in Xinjiang, China (in Chinese with English abstract). Volcanol Min Resour, 2001, 22: 252-263

$90 \mathrm{Gu}$ L X, Zhu J L, Guo J C, et al. Geology and Genesis of the Mafic-Ultramafic complexes in the Huangshan-Jingerquan (HJ) Belt, East Xinjiang. Chin J Geochem, 1995, 14: 97-116

91 Qin K Z, Sun S, Li J L, et al. Paleozoic epithermal $\mathrm{Au}$ and $\mathrm{Cu}$ deposits in North Xinjiang, China: Epochs, features, tectonic linkage and exploration significance. Resour Geol, 2002, 52: 291-300

92 Li J Y, Xiao W J, Wang K Z, et al. Neoproterozoic-Paleozoic tectonostratigraphic framework of Eastern Xinjiang, NW China. In: Mao J W, Goldfarb R, Seltmann R, et al, eds. Tectonic Evolution and Metallogeny of the Chinese Altay and Tianshan. London: Natural History Museum, 2003. 31-74

93 Wang B, Cluzel D, Shu L S, et al. Evolution of calc-alkaline to alkaline magmatism through Carboniferous convergence to Permian transcurrent tectonics, western Chinese Tianshan. Int J Earth Sci, 2009, 98: 1275-1298

94 Qian Q, Gao J, Klemd R, et al. Early Paleozoic tectonic evolution of the Chinese South Tianshan orogen: Constraints from SHRIMP zircon U-Pb geochronology and geochemistry of basaltic and dioritic rocks from Xiate, NW China. Int J Earth Sci, 2009, 98: 551-569

95 Konopelko D, Biske G, Seltmann R, et al. Deciphering Caledonian events: Timing and geochemistry of the Caledonian magmatic arc in the Kyrgyz Tien Shan. J Asian Earth Sci, 2008, 32: 131-141

96 Mikolaichuk A V, Kotov V V, Kuzikov S I. Structural position of the Malyi Naryn metamorphic complex as related to the problem of the boundary between the North and Median Tien Shan. Geotectonics, 1995, 29: 157-166

97 Wang B, Chen Y, Zhan S, et al. Primary Carboniferous and Permian paleomagnetic results from the Yili Block (NW China) and their geodynamic implications on the evolution of Chinese Tianshan Belt. Earth Planet Sci Lett, 2007, 263: 288-308

98 Levashova N M, Degtyarev K Y, Bazhenov M L, et al. Middle Paleozoic paleomagnetism or east Kazakhstan: Post-Middle Devonian rotations in a large-scale orocline in the Central Ural-Mongol belt. Tectonophysics, 2003, 377: 249-268

99 Carroll A R, Liang Y H, Graham S A, et al. Junggar Basin, NW China: trapped Late Paleozoic ocean. Tectonophysics, 1990, 181: $1-14$

100 Zheng J, Sun M, Zhao G C, et al. Elemental and Sr-Nd isotopic 
geochemistry of Late Paleozoic volcanic rocks beneath the Junggar basin, NW China: Implications for the formation and evolution of the basin basement. J Asian Earth Sci, 2006, 29: 778-794

101 Zhao J M, Liu G D, Lu Z X, et al. Lithospheric structure and dynamic processes of the Tianshan orogenic belt and the Junggar Basin. Tectonophysics, 2003, 376: 199-239

102 Teng J W, Zeng R S, Yan Y F, et al. Depth distribution of Moho and tectonic framework in eastern Asian continent and its adjacent ocean areas. Sci China Ser D-Earth Sci, 2003, 46: 428-446

103 Davies J H, von Blanckenburg F. Slab breakoff: A model of lithosphere detachment and its test in the magmatism and deformation of collisional orogens. Earth Planet Sci Lett, 1995, 129: 85-102

104 Regard V, Facenna C, Bellier O, et al. Laboratory experiments of slab break-off and dip reversal: Insight into the Alpine Oligocene reorganization. Terra Nova, 2008, 20: 267-273

105 Feng Y, Coleman, R G, Tilton G, et al. Tectonic evolution of the west Junggar region, Xinjiang, China. Tectonics, 1989, 8: 729-752

106 Van der Voo R, Levashova N M, Skrinnik L I, et al. Late orogenic, large-scale rotations in the Tien Shan and adjacent mobile belts in Kyrgystan and Kazakhstan. Tectonophysics, 2006, 426: 335-360

107 Abrajevitch A, Van der Voo R, Bazhenov M L, et al. The role of the Kazakhstant orocline in the late Paleozoic amalgamation of Eurasia. Tectonophysics, 2008, 455: 61-76

108 Cocks L R M, Torsvik T H. Siberia, the wandering northern terrane, and its changing geography through the Palaezoic. Earth Sci Rev, 2007, 82: 29-74

109 Rong J Y, Zhang Z X. A southward extension of the Silurian Tuvaella brachiopod fauna. Lethaia, 1982, 15: 133-147

110 Li Y J, Sun L D, Wu H R, et al. Permo-Carboniferous radiolaria from the Wupatarkan Group, west terminal of Chinese South Tianshan (in Chinese with English abstract). Chin J Geol, 2005, 40:
220-226

111 Lomize M G, Demina L I, Zarshchikov A A. The Kyrgyz-Terskei Paleoceanic Basin, Tien Shan. Geodynamics, 1997, 6: 35-55

112 Zonenshain L P, Kuzmin M I, Natapov L A. Geology of the USSR: A plate-tectonic synthesis. Amer Geophys Union Geody Ser, 1990, 21: 242

113 Chiaradia M, Konopelko D, Setmann R, et al. Lead isotope variations across terrane boundaries of the Tien Shan and Chinese Altay. Miner Deposita, 2006, 41: 411-728

114 Mao J W, Konopelko D, Seltmann R, et al. Postcollisional age of the Kumtor gold deposit and timing of Hercynian events in the Tien Shan, Kyrgyzstan. Econ Geol, 2004, 99: 1771-1780

115 Solomovich L I, Trifonov B A. Postcollisional granites in the South Tien Shan Variscan Collisional Belt, Kyrgystan. J Asian Earth Sci, 2002, 21: 7-21

116 Solomovich L I. Postcollisional magmatism in the South Tien Shan Variscan Orogenic Belt, Kyrgystan: Evidence for high-temperature and high-pressure collision. J Asian Earth Sci, 2007, 30: 142-153

117 Burtman V S. Structural geology of Variscan Tien Shan, USSR. Amer J Sci, 1975, 275A: 157-186

118 Filippova I B, Bush V A, Didenko A N. Middle Paleozoic subduction belts: The leading factor in the formation of the Central Asian fold-and-thrust belt. Russian J Earth Sci, 2001, 3: 405-426

119 Alekseev D V, Aristov V A, Degtyarev K E. The age and tectonic setting of volcanic and cherty sequences in the ophiolite complex of the Atbashe Ridge (Southern Tien Shan). Doklady Earth Sci, 2007, 413: $380-383$

120 Konopelko D, Seltmann R, Biske G, et al. Possible source dichotomy of contemporaneous post-collisional barren I-type versus tinbearing A-type granites, lying on opposite sides of the South Tien Shan suture. Ore Geol Rev, 2009, 35: 206-216 